\title{
Schwann Cells Express Active Agrin and Enhance Aggregation of Acetylcholine Receptors on Muscle Fibers
}

\author{
Jie-Fei Yang, Guan Cao, Samir Koirala, Linga V. Reddy, and Chien-Ping Ko \\ Section of Neurobiology, Department of Biological Sciences, University of Southern California, Los Angeles, California \\ 90089-2520
}

To explore novel roles of glial cells in synaptic function and formation, we examined the expression of agrin in frog Schwann cells and tested their role in the aggregation of acetylcholine receptors (AChRs). Using reverse transcription-PCR, we found that Schwann cells along nerve fibers in tadpoles expressed only the inactive agrin isoform B0 but began to also express active agrin isoforms B11 and B19 at approximately metamorphosis. During nerve regeneration in the adult, the expression of these active agrin isoforms in Schwann cells was upregulated, including the appearance of the most potent isoform, B8. This upregulation was induced by regenerating axons but not by nerve injury per se. In muscle cultures, the presence of adult Schwann cells enhanced the number and the total area of AChR aggregates 2.2- and 4.5-fold, respectively, and this enhancement was eliminated by heparin treatment. Further- more, adult Schwann cells in culture expressed active agrin isoforms and produced agrin protein. Using a novel technique to selectively ablate perisynaptic Schwann cells (PSCs) at the neuromuscular junction, we found that PSCs also expressed active agrin isoforms $\mathrm{B} 11$ and $\mathrm{B} 19$, and these active isoforms were upregulated, including the appearance of B8, during reinnervation. Observation in vivo showed that extrajunctional AChR aggregates were associated with PSC sprouts after nerve injury and subsequent reinnervation. These results suggest that, contrary to the prevailing view that only neurons express active agrin, glial cells also express active agrin and play a role in the aggregation of AChRs both in vitro and in vivo.

Key words: acetylcholine receptors; agrin; complement; frog; glia; muscle; neuromuscular junction; nerve regeneration; Schwann cells
Glial cells outnumber neurons and are widely distributed throughout the nervous system, including at the chemical synapse. However, our knowledge of the role of glial cells in the synapse is rudimentary. As with other chemical synapses, the neuromuscular junction (NMJ) is composed of three intimately juxtaposed cellular elements: the presynaptic nerve terminal, the postsynaptic specializations, and synapse-associated glial cells. Previous studies on the NMJ, the best-understood synapse, have focused almost exclusively on the role of the presynaptic nerve terminal and the postsynaptic specializations (Sanes and Lichtman, 1999). The role of synapse-associated glial cells, which are called perisynaptic Schwann cells (PSCs) (also known as terminal Schwann cells) at the NMJ, has been overlooked until recently. One of the key findings regarding the role of PSCs is that PSCs sprout profusely after nerve injury and lead regenerating axons and nerve terminal sprouts (Reynolds and Woolf, 1992; Son and Thompson, 1995a,b; O’Malley et al., 1999; Koirala et al., 2000). Nerve terminals also grow along the preceding PSC sprouts seen during synaptic remodeling in intact frog muscles (Chen et al., 1991; Chen and Ko, 1994; Ko and Chen, 1996), as well as during

Received Aug. 7, 2001; revised Sept. 19, 2001; accepted Oct. 1, 2001.

This work was supported by National Institutes of Health Grant NS17954 and a Muscular Dystrophy Association research grant. We thank Dr. Earl W. Godfrey of Eastern Virginia Medical School for the generous gift of anti-agrin C3 monoclonal antibody and Dr. Bai Lu of National Institutes of Health for the generous gift of the anti-synapsin I antibody. We are grateful to Drs. John H. Caldwell, Earl W. Godfrey, and Karl W. K. Tsim for their critical comments. We also thank H. Qiang, T. Ma, Z. Feng, and C. David for their expert technical support.

Correspondence should be addressed to Dr. Chien-Ping Ko, Section of Neurobiology, Department of Biological Sciences, University of Southern California, Los Angeles, CA 90089-2520. E-mail: cko@mizar.usc.edu.

Copyright (C) 2001 Society for Neuroscience $0270-6474 / 01 / 219572-13 \$ 15.00 / 0$ synaptogenesis in tadpole muscles (Herrera et al., 2000). These studies suggest that PSCs play important roles in synaptic repair and growth (Son et al., 1996). It has also been shown that glial cells modulate synaptic function at the NMJ (Robitaille, 1998; Castonguay and Robitaille, 2001) and the CNS synapse (Araque et al., 1999; Bacci et al., 1999). Thus, glial cells should be viewed as an active partner of the tripartite chemical synapse in both the PNS and the CNS.

To further explore synapse-glial interactions, the present study aimed to test a hypothesis that glial cells play a role in the aggregation of acetylcholine receptors (AChRs). It has been well established that agrin plays a major role in the aggregation of AChRs and the differentiation of the postsynaptic apparatus at the NMJ (McMahan, 1990; Ruegg and Bixby, 1998; Sanes and Lichtman, 1999). Motor neurons express different isoforms of the agrin protein; three isoforms, B8, B11, and B19, with inserts of 8 , 11, and 19 amino acids, respectively, at the B (for chick and frog) $/ \mathrm{Z}$ (for rat) site are active in the aggregation of AChRs, and one isoform, B0, without the inserts, is inactive (Ferns et al., 1992, 1993; Ruegg et al., 1992; Tsim et al., 1992). Although various non-neuronal tissues, including muscle fibers, also express the inactive isoform of agrin (Ferns et al., 1992; Ruegg et al., 1992; Tsim et al., 1992; Ma et al., 1994; Smith and O'Dowd, 1994), the prevailing view is that only neurons express active isoforms of agrin and induce AChR aggregation (Ruegg and Bixby, 1998). However, it has not been rigorously tested whether and how Schwann cells express active agrin isoforms and whether Schwann cells also play a role in the aggregation of AChRs. The present study addressed these questions.

Parts of this work have been published previously in abstract form (Qiang et al., 1998; Cao et al., 1999; Yang and Ko, 1999). 


\section{MATERIALS AND METHODS}

Animals. Adult grass frogs (Rana pipiens) (7-8 cm rump-to-nose length; weighing 25-35 gm) were obtained from Charles Sullivan (Nashville, $\mathrm{TN}$ ) and maintained in the laboratory for at least 2 weeks before experiments. Frogs were kept at $24^{\circ} \mathrm{C}$ on a $12 \mathrm{hr}$ light/dark cycle in individual tanks and fed with mealworm (Tenebrio molitor) larvae twice a week. Adult Xenopus laevis were obtained from Nasco (Fort Atkinson, WI), bred following their methods, and embryos were staged according to the system of Nieuwkoop and Faber (1994). Tadpoles and juveniles of bullfrog (Rana catesbeiana) at different stages were obtained from Charles Sullivan.

Adult Schwann cell culture. Adult Xenopus sciatic nerves were dissected out, and epineurial membranes were removed. Nerves were cut into small pieces $(\sim 2 \mathrm{~mm})$ and digested with $0.3 \%$ collagenase and $0.25 \%$ trypsin-EDTA (Life Technologies, Gaithersburg, MD). Dissociated cells were plated on laminin-1-coated culture dishes with culture medium consisting of $45 \%$ Leibovitz's L-15 medium (Life Technologies), $45 \%$ Ringer's solution (in mM: $115 \mathrm{NaCl}, 2 \mathrm{CaCl}_{2}, 2.5 \mathrm{KCl}$, and $10 \mathrm{HEPES}$, $\mathrm{pH} 7.4$ ) and $10 \%$ fetal calf serum (Life Technologies). Serum-free medium, L-15/Ringer's solution $(1: 1, \mathrm{v} / \mathrm{v})$, was used from the second week and subsequently changed once every week. Because the sciatic nerve does not contain any neuronal cell bodies, it is virtually impossible that the Schwann cell culture would be contaminated with neurons. The identity of Schwann cells in culture was verified by staining with monoclonal antibody (mAb) 2A12 (Astrow et al., 1998) or anti-glial fibrillary acidic protein (GFAP) antibody (Georgiou et al., 1994). Only cultures containing $90 \%$ or more Schwann cells (the rest were fibroblasts) were used for coculturing with muscle. After Schwann cells had been cultured for 3-4 weeks, Xenopus muscle was added. Pure embryonic Xenopus muscle cultures were prepared according to Tabti and Poo (1994). Briefly, neural tubes and associated myotomal tissues of stage 21-23 Xenopus embryos were dissected, and myotomal tissues were detached from the neural tube after $15 \mathrm{~min} 0.1 \%$ collagenase treatment. The detached myotomal tissue was further dissociated in $\mathrm{Ca}^{2+}$ - and $\mathrm{Mg}^{2+}$ free Ringer's solution. The dissociated cells were then plated on either coverslips with adult Xenopus Schwann cells grown on them or coverslips coated with laminin- 1 . The culture medium contained $50 \%$ L-15 and $50 \%$ Ringer's solution. For heparin treatment, $300 \mu \mathrm{g} / \mathrm{ml}$ heparin $(\mathrm{H}-$ 3393; Sigma, St. Louis, MO) was included in the muscle medium or Schwann cell-muscle coculture medium. On day 7 in coculture, cultures were fixed with $2 \%$ paraformaldehyde and stained with Texas Redtagged $\alpha$-bungarotoxin ( $\alpha$-BTX) $(0.3 \mu \mathrm{g} / \mathrm{ml}$; Molecular Probes, Eugene, $\mathrm{OR}$ ) for $\mathrm{AChR}$ aggregates and mAb $2 \mathrm{~A} 12$ for Schwann cells. Images were captured with a Spot Digital Camera (Diagnostic Instruments, Sterling Heights, MI), and the number and size of AChR aggregates were analyzed using ImageTool (University of Texas Health Science Center at San Antonio, San Antonio, TX).

Reverse transcription-PCR. Adult frogs were anesthetized with 15-30 min immersion in $0.1 \%$ tricaine (3-aminobenzoic acid ethyl ester; Sigma). For the short-term denervation study, the sciatic nerve was transected and allowed to regenerate. For the long-term denervation study, a $5 \mathrm{~mm}$ segment of the sciatic nerve was removed, and the severed nerve was examined every 2 weeks to visually verify that the distal stump was completely segregated from the proximal stump. At different time points after axotomy, both distal and proximal nerve stumps were collected and analyzed by reverse transcription (RT)-PCR. Segments of these stumps were stained with anti-neurofilament 200 antibody (Sigma) to verify the presence or the absence of axons.

Tissues including spinal cord, sciatic nerve trunk, and cutaneous pectoris (CP) muscle of frog, or cultured cells were collected, frozen in liquid nitrogen, and stored at $-70^{\circ} \mathrm{C}$. The epineurial sheath, which contains fibroblasts, was routinely removed. Total RNAs of these tissues were isolated using QuickPrep Total RNA extraction kit (Amersham Pharmacia Biotech, Arlington Heights, IL) and were reverse transcribed using oligo-dT primer by First-Strand cDNA synthesis kit (Amersham Pharmacia Biotech). PCR reaction mixtures were prepared with cDNAs from reverse transcription using the PCR Supermix (Life Technologies). The PCR reaction was performed using the Robocycler Gradient 40 (Stratagene, La Jolla, CA) for 30 cycles of $94^{\circ} \mathrm{C}$ for $1 \mathrm{~min}, 57^{\circ} \mathrm{C}$ for 1.5 min, and $72^{\circ} \mathrm{C}$ for $1.5 \mathrm{~min}$ in a $50 \mu \mathrm{l}$ volume containing $0.8 \mathrm{~mm}$ dNTPs, $1 \times$ PCR buffer (20 mM Tris-HCl, pH 8.4, and $50 \mathrm{~mm} \mathrm{KCl}), 1.5 \mathrm{~mm}$ $\mathrm{MgCl}_{2}$, and $0.25 \mathrm{U}$ of Taq DNA-polymerase. The PCR cycle numbers and composition of the PCR buffer were optimized to fall in the linear range of signal. Primers flanking the frog agrin alternative splicing site $\mathrm{B}$ were designed based on the GenBank sequence under accession number
AF096690 (Werle et al., 1999): forward, 5' ${ }_{574}$ TTT GAC GGA AAG ACT TAC CTG ${ }_{594} 3^{\prime}$; ; and backward, $5^{\prime}{ }_{726}$ GGC TTC AGT CTT TAT GCT CAG CTC $7023^{\prime}$. The PCR products were analyzed on polyacrylamide gels following Sambrook and Russell (2001). After electrophoresis, the gels were visualized by UV transilluminator and imaged with a digital camera. The PCR fragments were subcloned into pCR2 vector (Invitrogen, Carlsbad, CA), and the identity of each fragment was confirmed by DNA sequencing (performed by Research Genetics, Huntsville, AL). Nested PCR was used to further confirm that the PCR products represented the frog agrin gene fragments. The internal nest primers (forward, 5' ${ }_{590}$ CCT GGA GTA CCA CAA A ${ }_{606} 3^{\prime}$; and backward, 5' ${ }_{707}$ AGC TCA AAT TCA TTG GT ${ }_{690} 3^{\prime}$ ) were located within the PCR fragment generated from the previous PCR reaction and thus were used to ensure the identity of those PCR products. To reveal the relative abundance of different agrin isoforms, bands of RT-PCR data were scanned, and the number of pixels in each band was calculated and expressed as the percentage of the total agrin isoforms within the same lane. To verify the absence of neuronal mRNA contamination in our samples, primers for Xenopus neurofilament were designed according to the GenBank sequence under accession number U85969 (Gervasi and Szaro, 1997): forward, 5' ${ }_{298}$ TAC ATC GAG AAG GTC CAT ${ }_{315} 3^{\prime}$; and backward, 5' ${ }_{1169}$ AAA AGT TTC CTG TAT GCA ${ }_{1152} 3^{\prime}$.

SDS-PAGE and immunoblotting. Schwann cells in culture $\left(5 \times 10^{6}\right.$ cells per lane) were collected by $0.25 \%$ trypsin-EDTA treatment and lysed in a buffer containing $2 \%$ SDS and $62.5 \mathrm{~mm}$ Tris- $\mathrm{HCl}, \mathrm{pH} 7.4$. Conditioned media from Schwann cell and muscle cocultures or from pure muscle cultures were concentrated using Microcon-30 (Millipore, Bedford, MA). The concentrated media or the total lysate of Schwann cells were collected and prepared for SDS-PAGE (Sambrook and Russell, 2001).

After electrophoresis, proteins in the polyacrylamide gels were transferred to a polyvinylidene difluoride membrane (Immobilon-P; Millipore) using a Mini Trans-Blot Cell (Bio-Rad, Hercules, CA). The membrane was stained with Ponceau S [0.1\% Ponceau S (w/v) in 5\% acetic acid $(\mathrm{v} / \mathrm{v})]$ to confirm the presence of proteins. The membrane was blocked with $5 \%$ dry nonfat milk in Tris-buffered saline-Tween 20 (TBS-T) (20 mm Tris, $0.14 \mathrm{M} \mathrm{NaCl}, \mathrm{pH} \mathrm{7.6}$, and $0.1 \%$ Tween 20) for $1 \mathrm{hr}$ at room temperature, followed by incubation with anti-agrin mAb C3 (a kind gift from Dr. Earl W. Godfrey, Eastern Virginia Medical School, Norfolk, VA) (Godfrey et al., 1988) at 1:100 for $1 \mathrm{hr}$ at room temperature. The membrane was thoroughly washed with TBS-T before it was further incubated with alkaline phosphatase-conjugated goat anti-mouse IgG secondary antibody for $1 \mathrm{hr}$ at room temperature. After TBS-T rinses, immunoreactivity was detected using Alkaline Phosphatase Conjugate Substrate kit (Bio-Rad).

PSC ablation in the cutaneous pectoris muscle. Affinity-purified $\mathrm{mAb}$ 2A12 (Astrow et al., 1998) [60 $\mu \mathrm{g} / \mathrm{ml}$ in $100 \mu \mathrm{l}$ of normal frog Ringer's solution (NFR)] was injected bilaterally beneath the frog CP muscle. The $\mathrm{CP}$ muscles were dissected the next day and incubated in guinea pig complement at $30^{\circ} \mathrm{C}$ for $1 \mathrm{hr}$. The guinea pig complement was diluted with additional $40 \%$ distilled water to maintain normal frog osmolarity. Immediately after the complement treatment, the $\mathrm{CP}$ muscle on one side was then taken for RT-PCR sampling by separating the NMJ-rich and NMJ-poor regions according to the innervation pattern visible under a dissecting microscope. The contralateral muscle was used to confirm PSC cell death by staining with ethidium homodimer-1 (EthD-1) (1:500 in NFR; Molecular Probes) and FITC-peanut agglutinin (PNA) (1:100 in NFR) for 1 hr. EthD-1 labels nuclei of lysed cells, whereas PNA recognizes the extracellular matrix associated with PSCs (Ko, 1987).

Observation of extrajunctional AChR aggregates in the frog muscle. Adult frogs were anesthetized by $15-30 \mathrm{~min}$ immersion in $0.1 \%$ tricaine, and the nerve to the $\mathrm{CP}$ muscle was transected 1-2 $\mathrm{mm}$ from the muscle. This denervation procedure permits reinnervation of the muscle beginning at $\sim 14 \mathrm{~d}$ after axotomy. At 17-28 d after axotomy, animals were killed, and CP muscles were dissected. Muscles in whole mount were treated with $3 \%$ normal goat serum in NFR for $45-60$ min, after which they were incubated overnight in $7.2 \mu \mathrm{g} / \mathrm{ml} \mathrm{mAb} 2 \mathrm{~A} 12$ in NFR. Biotinylated goat anti-mouse IgM $\mu$-specific secondary antibody (Sigma) was applied for $45 \mathrm{~min}$ at 1:50 in NFR, along with Texas Red-tagged $\alpha$-BTX at $0.5 \mu \mathrm{g} / \mathrm{ml}$. After $30 \mathrm{~min}$ wash with NFR, the muscle was fixed in $2 \%$ paraformaldehyde for $30 \mathrm{~min}$. In some cases, instead of $\alpha$-BTX, a monoclonal antibody against the $\delta$ subunit of the nicotinic AChR (Affinity BioReagents, Golden, $\mathrm{CO}$ ) was used at 1:400 after fixation. 7-amino-4methylcoumarin-3-acetic acid-tagged streptavidin at 1:50 or 1:75 was applied to reveal mAb 2A12, and Texas Red-tagged goat anti-mouse IgG 
at 1:400 revealed the anti-AChR $\delta$ antibody. Muscles were rinsed again and then treated for $45-60$ min with $5 \%$ goat serum in frog PBS containing $0.5 \%$ Triton X-100 (PBS-T). Anti-synapsin I (polyclonal antibody kindly provided by Dr. Bai Lu, National Institutes of Health, Bethesda, MD) and anti-neurofilament $200 \mathrm{kDa}$ (Sigma) antibodies, diluted 1:300 and 1:400, respectively, in $0.5 \%$ PBS-T containing 5\% goat serum, were applied overnight. These antibodies were revealed using 1:150 FITC-tagged goat anti-rabbit IgG and 1:400 FITC-tagged goat anti-mouse $\operatorname{IgG} \gamma$-specific secondary antibodies, respectively, in $0.3 \%$ PBS-T containing 5\% goat serum. After rinsing with PBS and stripping the muscles of excess connective tissue, the muscles were post-fixed for 30 min in $2 \%$ paraformaldehyde. Histological staining for acetylcholinesterase (AChE) was performed according to the method of Karnovsky (1964). Finally, the muscles were mounted on glass slides in Citifluor mountant (Ted Pella Inc., Redding, CA) and viewed under fluorescence optics. Digital images were captured, and measurements of length and area were made using the Scion Image program (Scion Corp., Frederick, MD). Measurements are mean \pm SEM.

To determine the properties of extrajunctional AChR aggregates and their association with PSCs, four measurements were made: 1, size (length along major axis) of AChR aggregate; 2, distance from closest axon or nerve terminal; 3, distance from the closest PSC process; and 4, distance from the original synapse (marked by AChE stain). Extrajunctional AChR "aggregates" were defined as $\alpha$-BTX- or anti-AChR $\delta$ antibody-positive clusters that measured $10 \mu \mathrm{m}$ or greater in length and were at least $10 \mu \mathrm{m}$ away from AChE-stained original sites. AChR aggregates were considered to be associated with PSCs alone when the aggregates overlapped with 2A12 staining and were at least $10 \mu \mathrm{m}$ away from synapsin I- or neurofilament 200-stained processes. All measurements were restricted to the area on each muscle fiber extending $200 \mu \mathrm{m}$ beyond either end of an NMJ; AChR aggregates were very rare outside of this area.

It is important to rule out the possibility that AChR aggregates may be associated with PSCs purely by chance. Our approach was to determine the proportion of observed muscle area occupied by PSC sprouts and then calculate the relative probability that randomly distributed AChR aggregates would fall within this area. For muscle fibers with PSCassociated AChR aggregates, the average PSC sprout area (without nerve terminals or axons) was $\sim 330 \mu \mathrm{m}^{2}$. The total observed area per muscle fiber was $\sim 57350 \mu \mathrm{m}^{2}$. After excluding original junctional sites, as well as areas under axons and nerve terminals, the total extrajunctional muscle area was $\sim 52950 \mu \mathrm{m}^{2}$. Within this extrajunctional area, an AChR aggregate could randomly either fall within the area occupied by PSC sprouts $\left(330 \mu \mathrm{m}^{2}\right)$ or outside $\left(52620 \mu \mathrm{m}^{2}\right)$. The ratio of PSC sprout area to surrounding muscle area is $\sim 1: 160$ (330:52620). Therefore, if extrajunctional AChR aggregates were randomly distributed over the muscle surface, only $0.6 \%$ (1 of 160 ) would be expected to colocalize with PSC sprouts alone. Our observed results were compared with these expected results for random association using the $\chi^{2}$ test.

\section{RESULTS}

\section{Expression of agrin isoforms in developing and adult Schwann cells}

Previous molecular cloning studies have shown that motor neurons express four isoforms of agrin that contain either $0,8,11$, or 19 amino acids at the B (for chick and frog) or Z (for rat) site (Ferns et al., 1992; Ruegg et al., 1992; Tsim et al., 1992; Werle et al., 1999). Only B8, B11, and B19 isoforms are capable of inducing AChR aggregation at the NMJ, whereas B0 is inactive in inducing AChR aggregation (Ferns et al., 1992, 1993; Ruegg et al., 1992; Gesemann et al., 1995; Daggett et al., 1996). To investigate expression of agrin isoforms in glial cells, Schwann cells along the sciatic nerves of adult frogs (Rana pipiens) were examined by RT-PCR. Although the predominant cell type in the sciatic nerve is the Schwann cell, the epineurial sheath, which is rich in fibroblasts, was routinely removed to ensure that we used primarily Schwann cells for the RT-PCR study. We found that frog Schwann cells along the sciatic nerve expressed not only the inactive isoform B0, as shown previously (Werle et al., 1999), but also the active isoforms B11 and B19 (Fig. $1 A$, lane 6 ). To confirm the identity of agrin transcripts in Schwann cells, each PCR

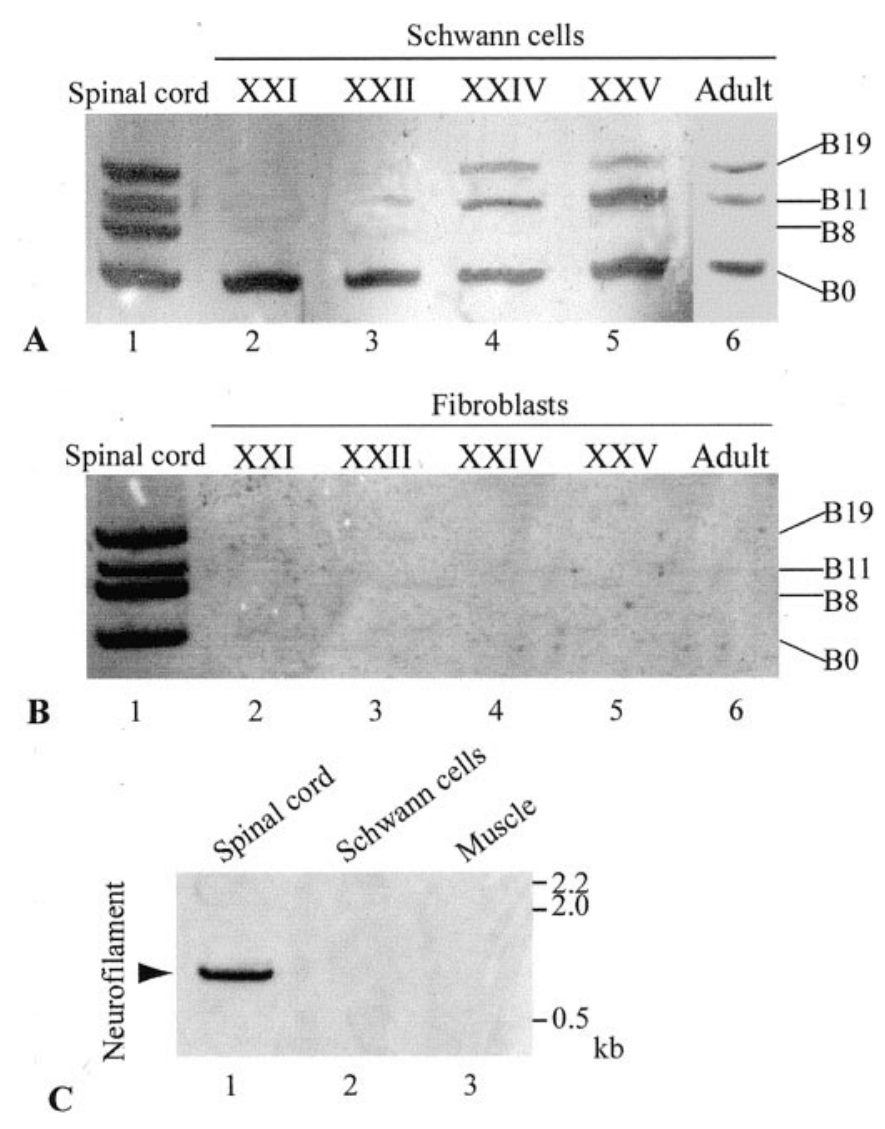

Figure 1. Expression of agrin isoforms in developing and adult Schwann cells. $A$, Expression of agrin isoforms in Schwann cells along the sciatic nerve in adult and bullfrog tadpoles at different developmental stages was examined by RT-PCR. Lane 1, The spinal cord of stage XXII bullfrog tadpoles showed all four isoforms of agrin: B0, B8, B11, and B19. Lane 2, Schwann cells at stage XXI expressed only the inactive B0 isoform. Lane 3, A trace amount of the B11 isoform was detected in Schwann cells at stage XXII. Lanes 4, 5, Schwann cells at stages XXIV and XXV expressed active isoforms B11 and B19 besides B0. Lane 6, Adult Schwann cells expressed three agrin isoforms, B0, B11, and B19, but did not show B8. $B$, Fibroblasts in the epineurial sheath of the sciatic nerve in bullfrog tadpoles at stages XXI-XXV (lanes 2-5) and in adult (lane 6) did not express any agrin isoforms. As a positive control, the adult spinal cord expressed all four agrin isoforms (lane 1). C, RT-PCR showed neurofilament mRNA fragment $(0.87 \mathrm{~kb})$ in the frog spinal cord tissue (lane 1, arrow) but not in Schwann cells along the sciatic nerve (lane 2) or muscle (lane 3).

fragment was subcloned and sequenced. PCR with nested primers (see Materials and Methods) were also used to further confirm that these PCR products were frog agrin gene fragments (Werle et al., 1999). Our results showed that agrin expression in adult Schwann cells was similar to that in the spinal cord neurons, except for the absence of the B8 isoform. In contrast to Schwann cells, the epineurial sheath, which is rich in fibroblasts, of the frog sciatic nerve showed no agrin expression at all (Fig. 1B, lane 6). To exclude the possibility of contamination with neuronal $\mathrm{mR}$ NAs in the sciatic nerve preparation, we performed RT-PCR for neurofilament, a neuron-specific marker. As expected, spinal cord tissue expressed neurofilament transcripts (Fig. 1C, lane 1, arrow). However, neurofilament transcripts were expressed in neither Schwann cells along the sciatic nerve (Fig. 1C, lane 2) nor muscle tissue (Fig. 1C, lane 3). Thus, it is unlikely that our sciatic nerve sample is contaminated with neuronal mRNAs. It is most likely that the active agrin isoforms seen in the sciatic nerve are ex- 
pressed by Schwann cells rather than by neurons or fibroblasts (see Discussion).

To determine the expression of active agrin isoforms in Schwann cells during development, sciatic nerves from tadpoles of bullfrog (Rana catesbeiana) at different developmental stages were examined. Bullfrog tadpoles were chosen because their large size provided ample developing Schwann cells for analysis. Before the onset of metamorphosis (stage XXI), Schwann cells along the sciatic nerve expressed only the inactive isoform B0 (Fig. 1A, lane 2). During and after metamorphosis (stages XXII to XXV), Schwann cells began to express active isoforms B11 and $\mathrm{B} 19$, in addition to $\mathrm{B} 0$ (Fig. $1 A$, lanes 3-5). Similar to adult Schwann cells (Fig. 1A, lane 6), developing Schwann cells did not express B8. In contrast, spinal cord neurons of the above developmental stages, as well as in adult, expressed all four isoforms (Fig. 1A, B, lane 1). Similar to adult fibroblasts (Fig. 1B, lane 6), fibroblasts in the epineurial sheath of the sciatic nerve in tadpoles at various stages expressed neither B0 nor active agrin isoforms (Fig. 1B, lanes 2-5).

\section{Expression of agrin isoforms in adult Schwann cells after axotomy}

To examine whether and how axons regulate the expression of adult Schwann cell agrin, we compared Schwann cells along the frog (Rana pipiens) sciatic nerve after short-term denervation, in which nerve regeneration was allowed, with Schwann cells after long-term denervation, in which nerve regeneration was prevented. The result of the short-term denervation is shown in Figure 2, $A$ and $B$. As expected from the above study (Fig. $1 A$, lane 6 ), adult Schwann cells in intact frog sciatic nerve expressed B0, B11, and B19 (Fig. 2A, Intact). Two weeks after axotomy, Schwann cells along nerve fibers (Fig. $2 A, 2 w$ ) began to show upregulation of active agrin isoforms in both proximal and distal nerve segments. In addition to the upregulation of B11 and B19, the most potent isoform in AChR aggregation, B8, now appeared. At this time after the short-term denervation, axons began to reinnervate through the distal nerve stump, as revealed by antineurofilament 200 staining (data not shown). To examine Schwann cell agrin upregulation after axonal regeneration, each lane in Figure $2 A$ (Distal) was analyzed based on the area and intensity of each band (see Materials and Methods). This information allowed us to reveal the relative abundance, and changes in the expression pattern, of different agrin isoforms after nerve injury. Figure $2 B$ shows the percentage of all active agrin isoforms combined (B8/B11/B19) relative to the total isoforms (active plus inactive) within each individual lane at various time periods after axotomy. The percentages of B8 and B0 in each lane were also plotted individually. In Schwann cells along the intact nerve, B11/B19 constituted $<45 \%$ of total agrin isoforms. Two weeks after axotomy, the active isoforms, including B8, constituted over $60 \%$ of total agrin. This upregulation of active agrin became more prominent as regeneration progressed and peaked $\sim 6-7$ weeks after nerve transection. During this peak expression, there was a concomitant decrease in the relative percentage of B0, and the pattern of Schwann cell agrin expression closely resembled neuronal agrin expression (Fig. $2 A, 4 w-8 w$, compare with Fig. $1 A, B$, lane 1$)$. From 8 weeks after axotomy, the active isoforms began to show downregulation (Fig. $2 B$ ). However, 12 weeks after a single nerve transection, when nerve regeneration was complete, the active agrin expression level in Schwann cells remained slightly higher than that in Schwann cells along intact nerves, and a trace amount of B8 $(3 \%)$ could still be detected
(Fig. $2 A, B$ ). Whether or not the normal expression pattern would be totally restored beyond 12 weeks after axotomy was not examined.

To confirm that the upregulation of active agrin was triggered by axonal regeneration instead of simply by nerve injury per se, we also examined agrin expression in Schwann cells after longterm denervation (Fig. 2C,D). At 2 weeks after axotomy, the proximal nerve stump showed positive neurofilament staining (Fig. $2 C$, top right panel), indicative of nerve regeneration, but the disconnected distal stump was absent of neurofilament staining (Fig. 2C, bottom right panel). As expected for regenerated nerves (Fig. $2 A, B)$, Schwann cells in the proximal nerve segment expressed all four isoforms of agrin (Fig. $2 C$, top left panel). In contrast, Schwann cells in the chronically denervated distal segment expressed only B0, B11, and B19 and not B8 (Fig. 2C, middle left panel ). At 4-6 weeks after chronic denervation, the contrast between the upregulation of active agrin in the proximal stump and its absence in the distal stump became even more prominent. Similar to the intact sciatic nerve (Fig. 1C), Schwann cells in the regenerated proximal stump 2-6 weeks after axotomy did not express neurofilament mRNA (Fig. $2 C$, bottom left panel). Thus, the appearance of B8 isoform in the proximal Schwann cells after nerve regeneration is likely not a contamination of neuronal agrin mRNA. The difference in the relative expression of active versus inactive isoforms between Schwann cells in the proximal and distal segments is further shown in Figure 2D. Schwann cells along the proximal nerve stump showed upregulation of all active agrin isoforms from $45 \%$ to over $65 \%$ and $\mathrm{B} 8$ from $0 \%$ to over $17 \%$, relative to the total agrin isoforms at 4-6 weeks after axotomy. In contrast, Schwann cells in the distal nerve segment showed a total absence of B8 and no upregulation of the other active isoforms, which remained $\sim 44-48 \%$ up to 6 weeks after long-term denervation. These results suggest that upregulation of active agrin isoforms in Schwann cells is not induced by nerve injury per se but instead by nerve regeneration.

\section{Adult Schwann cells enhance AChR aggregation on muscle in culture}

Because adult Schwann cells express active agrin isoforms, we investigated whether these glial cells play a role in the aggregation of AChRs on muscle fibers. To address this question, Xenopus cultures were used for functional assay. Schwann cells obtained from adult Xenopus sciatic nerves were cocultured with primary Xenopus myotubes, which were prepared from stage 21-23 embryos. In culture, these Schwann cells de-differentiate to a nonmyelinating phenotype (Brockes et al., 1979), similar to PSCs. All cultures contained similar density of Schwann cells at $\sim 15,000$ cells per dish (35 mm in diameter). The identity of Schwann cells in vitro was confirmed by positive staining with mAb $2 \mathrm{~A} 12$ that recognizes the Schwann cell membrane (Astrow et al., 1998) or with anti-GFAP antibody (Georgiou et al., 1994). Embryonic Schwann cells were not used because they expressed only the inactive B0 isoform as shown above. To analyze the effect of Schwann cells on AChR aggregation, we compared AChR clusters on muscle fibers grown in the presence of adult Schwann cells $(\mathrm{SC}+\mathrm{M})$ with those on muscle grown alone $(\mathrm{M})$ in culture. Neurons were not added to either of these cultures, and the absence of neuronal contamination was further verified by the absence of staining with anti-neurofilament antibody in these cultures (data not shown). Figure 3 shows an example of an $\mathrm{SC}+\mathrm{M}$ culture $\left(A, A^{\prime}\right)$ and an $\mathrm{M}$ culture $\left(B, B^{\prime}\right) 7 \mathrm{~d}$ in culture. The 
Figure 2. Upregulation of active agrin isoforms in adult Schwann cells induced by nerve regeneration. Expression of agrin isoforms in the Schwann cells along the frog sciatic nerve after shortterm denervation $(A, B)$ and long-term denervation $(C, D)$ was examined by RT-PCR. $A$, Schwann cells in the intact sciatic nerve expressed only three agrin isoforms: B0, B11, and B19. However, after a single nerve transection that allowed nerve regeneration, Schwann cells in both the proximal and the distal nerve stumps upregulated the expression of active isoforms, including the appearance of B8. The number of weeks after axotomy is denoted on the top of each lane. $B$, A plot shows changes in the percentage of $\mathrm{B} 0$ (filled circles), B8 (open triangles), and all active isoforms (B8/B11/B19; filled triangles) relative to the total isoforms (see Materials and Methods) at different time points after short-term denervation ( $n=3$ experiments; mean \pm SEM). The increase in the relative expression of active agrin and a concomitant decrease in $\mathrm{B} 0$ began at $\sim 2$ weeks and peaked at $\sim 6-7$ weeks after short-term denervation. A trace amount of B8 (3\%) was still detected 12 weeks after axotomy. $C$, Schwann cells in the sciatic nerve segment proximal to the transection site 2-6 weeks after long-term denervation upregulated the active agrin isoforms compared with the intact nerve (top left panel). The same Schwann cell samples along the intact nerve and the proximal nerve segment 2-6 weeks after axotomy did not show any neurofilament mRNA, in contrast to the spinal cord (bottom left panel). The proximal segment contained regenerating axons, as revealed by positive anti-neurofilament staining (top right panel). In contrast, the distal segment, which was chronically severed from the proximal segment, was absent of antineurofilament staining (bottom right panel). Schwann cells in the distal segment showed neither upregulation of B11 and B19 nor appearance of B8 (middle left panel). D, A plot shows an increase in the relative expression of all agrin isoforms (B8/B11/B19; filled triangles) and $\mathrm{B} 8$ (open triangles) in the proximal segment after long-term denervation. However, in the chronically segregated distal segment, the relative expression of the total active isoforms (B8/B11/B19; filled squares) remained unchanged, and no B8 (open squares) was detected up to 6 weeks after axotomy ( $n=3$ experiments; mean \pm SEM).

general cellular morphology in both cultures appeared similar under phase-contrast optics $(A, B)$. In addition, there was no significant difference in muscle fiber length between $\mathrm{SC}+\mathrm{M}$ culture $(241.8 \pm 51.2 \mu \mathrm{m}$; mean $\pm \mathrm{SD} ; n=96)$ and $\mathrm{M}$ culture $(221.6 \pm 33.2 \mu \mathrm{m} ; n=98)$. However, as shown with fluorescence staining, there were more and larger AChR clusters (arrowheads in $A^{\prime}$ and $B^{\prime}$ ) labeled with $\alpha$-BTX in $\mathrm{SC}+\mathrm{M}$ cultures than in $\mathrm{M}$
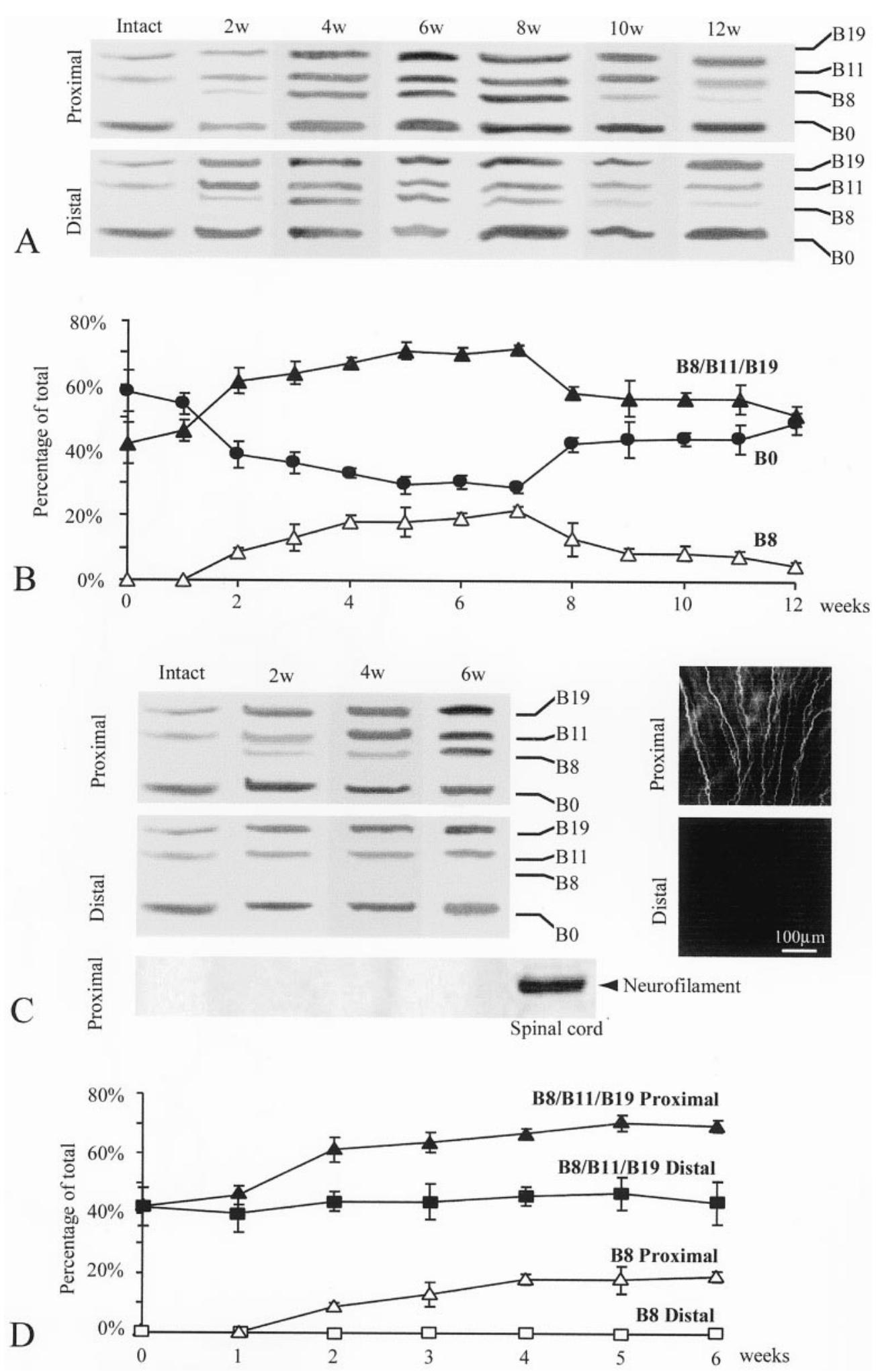

cultures (compare $A^{\prime}$ with $B^{\prime}$ ). The average number of AChR clusters per $100 \mu \mathrm{m}$ muscle length in the $\mathrm{SC}+\mathrm{M}$ culture was 2.2-fold $(p<0.001)$ of that in the $\mathrm{M}$ culture (Fig. 3C). The average area of individual AChR "hotspots" in the SC+M culture was $43.4 \pm 7.3 \mu \mathrm{m}^{2}$, which was significantly larger $(p<0.02)$ than the $22.7 \pm 3.7 \mu \mathrm{m}^{2}$ in the $\mathrm{M}$ culture. Thus, the total area of AChR clusters per $100 \mu \mathrm{m}$ muscle length in the $\mathrm{SC}+\mathrm{M}$ culture 
was also significantly enlarged $(p<0.001)$ to 4.5 -fold of that in the $\mathrm{M}$ culture (Fig. 3D).

To test whether AChR aggregates colocalized with contacts between Schwann cell processes and muscle fibers, we doublelabeled the $\mathrm{SC}+\mathrm{M}$ culture with mAb 2A12 for Schwann cells (Fig. $3 F$ ) and $\alpha$-BTX for AChRs (Fig. 3G). As shown in Figure $3 E$, contacts (arrows) between Schwann cell processes and muscle fibers were visualized with phase-contrast optics. Schwann cell processes were verified with mAb $2 \mathrm{~A} 12$ staining $(F)$. Although there were numerous AChR clusters (Fig. 3G,H, arrowheads) on the muscle fibers, most of them were not associated with Schwann cell processes. Only in rare cases were AChR clusters colocalized with Schwann cell-muscle contacts (Fig. 3E-H, asterisks). In 138 muscle fibers from nine cultures observed, $98.5 \%$ of AChR aggregates were not colocalized with Schwann cell-muscle contacts. This contrasts with nerve-muscle contacts, in which AChRs are clustered (Cohen et al., 1979; Frank and Fischbach 1979). Our results suggest that the increase in AChR aggregation by Schwann cells is likely mediated by soluble factors, such as agrin, released into the tissue culture medium.

\section{Is the increase in AChR aggregation by Schwann cells mediated by agrin?}

To determine whether the enhancement of AChR aggregation by Schwann cells might be mediated by agrin, we first verified with RT-PCR the expression of active agrin transcripts in cultured Schwann cells. As shown in Figure 4A, lane 3, Schwann cells grown alone in culture expressed not only B0 but also the active isoforms $\mathrm{B} 11$ and $\mathrm{B} 19$. The expression of these three isoforms was also seen in $\mathrm{SC}+\mathrm{M}$ culture (Fig. $4 A$, lane 4 ) throughout the coculture period. Similar to the expression pattern in adult Schwann cells after chronic denervation in vivo (Fig. 2C,D), B8 was not expressed in these "denervated" Schwann cells, either grown alone or with muscle, in culture. The absence of neurons was verified by the absence of neurofilament mRNA in these cultures (data not shown). Muscle cells grown alone in culture (M) expressed only the inactive isoform B0 (Fig. 4A, lane 2), whereas spinal neurons in culture (Fig. 4A, lane 1) expressed all four isoforms. Thus, Schwann cells, muscles, and neurons in vitro retain their characteristic expression pattern of agrin isoforms as seen in vivo.

To confirm that the expression of active agrin isoforms resulted in the production of agrin protein, lysate of cultured Schwann cell bodies was examined with Western blot using anti-Xenopus agrin mAb C3 (Godfrey et al., 1988). Similar to brain tissues (Fig. 4B, lane 2), cultured Schwann cells (Fig. 4B, lane 1) expressed native agrin protein at over $200 \mathrm{kDa}$. To determine whether agrin protein was released into the culture medium, Western blot of conditioned medium from Schwann cells cultured for 6 weeks was examined. As shown in Figure 4B, lane 3, the Schwann cellconditioned medium did contain the agrin protein (arrow), as also observed in the muscle-conditioned medium (lane 4) as a control. However, in contrast to the native agrin protein over $200 \mathrm{kDa}$ seen in Schwann cell bodies, the $70 \mathrm{kDa}$ band seen in the conditioned medium likely belongs to an inactive degraded product of the agrin protein, as shown previously in basal lamina extracts of the Torpedo electric organ (Nitkin et al., 1987). Consistent with the absence of native agrin protein bands above $200 \mathrm{kDa}$, we found that Schwann cell-conditioned medium added to $\mathrm{M}$ culture alone did not cause an increase in AChR aggregates (data not shown). This is contrary to the effect seen in SC $+\mathrm{M}$ coculture (Fig. 3), in which muscle fibers were probably exposed to a continuous supply of native agrin protein from cocultured Schwann cells (see Discussion).

To further determine whether Schwann cell-derived agrin might be involved in the enhancement of AChR aggregation, Schwann cell and muscle cocultures were treated with heparin (300 $\mu \mathrm{g} / \mathrm{ml})$, which has been shown to inhibit agrin-mediated AChR clustering on muscle (Hopf and Hoch, 1997). As shown in Figure 3,C and D, the number and the area of AChR hotspots in $\mathrm{SC}+\mathrm{M}$ cultures were significantly reduced by heparin treatment $(\mathrm{SC}+\mathrm{M}+\mathrm{H})$. However, spontaneous $\mathrm{AChR}$ aggregation, which is independent of agrin, was not affected in $\mathrm{M}$ cultures by heparin treatment. Although the direct evidence is lacking (see Discussion), the present data are consistent with the hypothesis that the enhancement of $\mathrm{AChR}$ aggregation seen in $\mathrm{SC}+\mathrm{M}$ cultures is mediated by Schwann cell-derived agrin.

\section{Agrin expression in the perisynaptic Schwann cell at the NMJ}

To investigate whether Schwann cells at the NMJ are similar to Schwann cells along the nerve with respect to expression of active agrin isoforms, we used a novel technique to selectively ablate PSCs in vivo (Reddy et al., 1999) (the detailed procedure of this technique will be described in a future paper). To ablate PSCs in vivo, we took advantage of mAb 2A12, which specifically labels the PSC surface membrane (Astrow et al., 1998). Labeling of PSCs with mAb $2 \mathrm{~A} 12$ followed by treatment with guinea pig complement results in the formation of membrane-attack complexes on PSCs. Membrane-attack complexes form pores on the cell membrane and cause the antibody-labeled cells to lyse (Howard and Hughes-Jones, 1988). To verify PSC lysis, EthD-1, which stains the nuclei of cells with damaged membranes, was applied after the complement treatment. As shown in Figure $5 A$, EthD-1 labeling (in red, arrows) colocalized with the soma of PSCs, which were revealed by mAb $2 \mathrm{~A} 12$ immunofluorescent staining (in green). Over $80 \%$ of PSCs were ablated using this treatment. In contrast to PSCs, Schwann cells along axons are not labeled with mAb 2A12 in whole mount because mAb 2 A12 does not penetrate the perineurium surrounding nerve fibers (Astrow et al., 1998) and thus are not lysed. We did not observe any morphological damage to nerve terminals or muscle fibers after mAb 2 A12 and complement treatment (L. V. Reddy, S. Koirala, Y. Sugiura, and C. P. Ko, unpublished observations). In control experiments using complement treatment alone, without 2A12 application, over $95 \%$ of PSCs were not lysed as indicated by the absence of EthD-1 labeling (Fig. 5B, arrows). Because mAb 2A12 was not used for the control, PSCs were revealed with FITCconjugated PNA (in green), which recognizes the extracellular matrix associated with PSCs (Ko, 1987). The few EthD-1-positive cells not colocalized with PSC cell bodies in the control were likely blood cells that are inevitably damaged during muscle dissection. The above results indicate that PSCs in situ can be selectively ablated using mAb $2 \mathrm{~A} 12$ followed by complement treatment (Reddy, Koirala, Sugiura and Ko, unpublished observations).

To test whether PSCs express active agrin isoforms, intact and PSC-ablated muscles were examined by RT-PCR (Fig. 5C). The central region of the $\mathrm{CP}$ muscle enriched in $\mathrm{NMJs}(N M J+)$ was separated from the remaining $\mathrm{NMJ}$-poor $(N M J-)$ region. In innervated muscles without PSC ablation (Fig. $5 C$ ), agrin isoforms B0, B11, and B19 were detected in the NMJ-rich region $(N M J+, P S C+$, lane 1). This expression pattern was similar to that of adult Schwann cells along intact nerve (Fig. $2 A$ ). In 

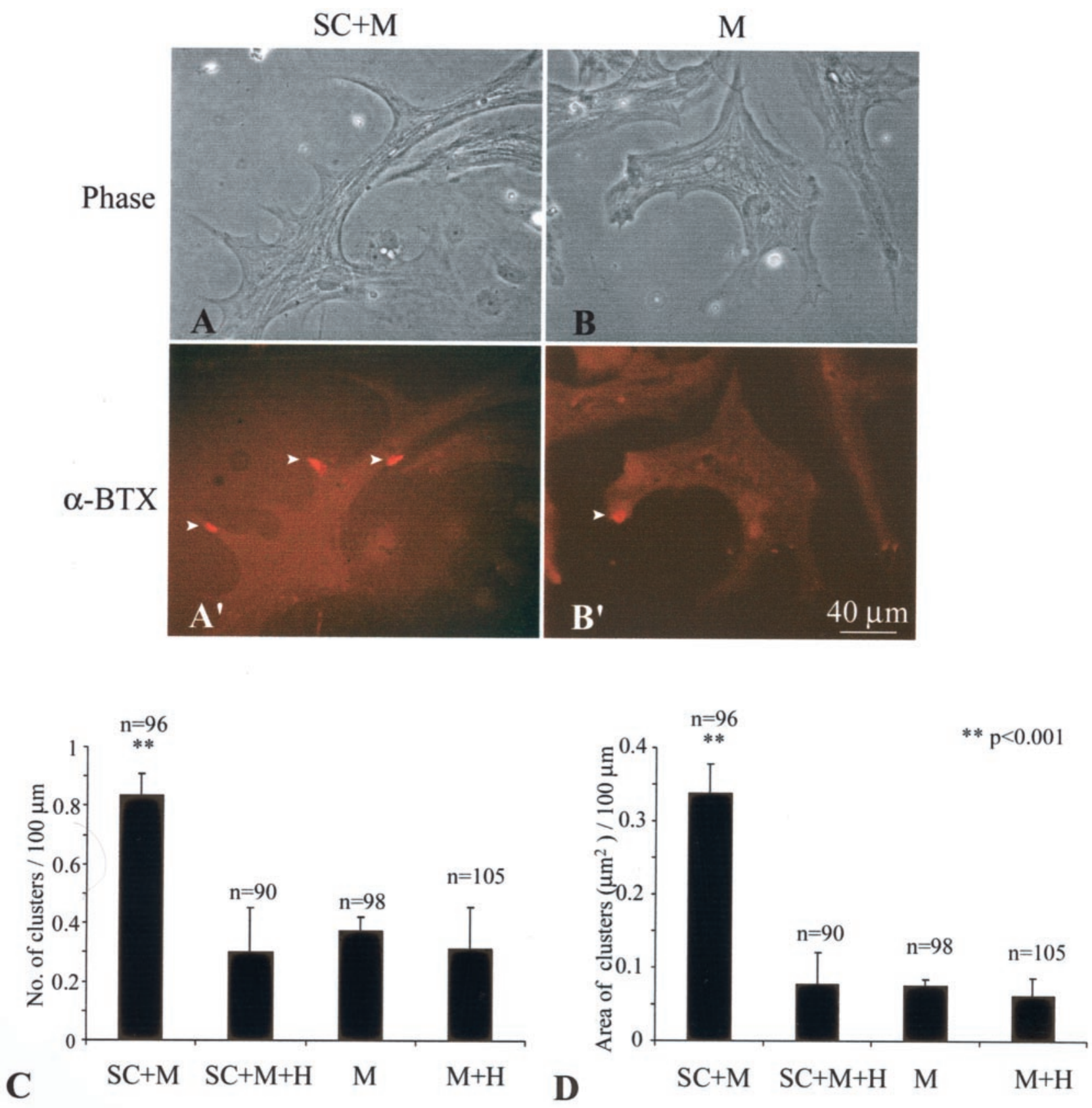

Phase

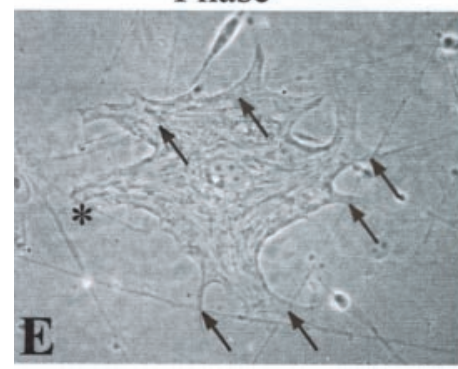

$2 \mathrm{~A} 12$

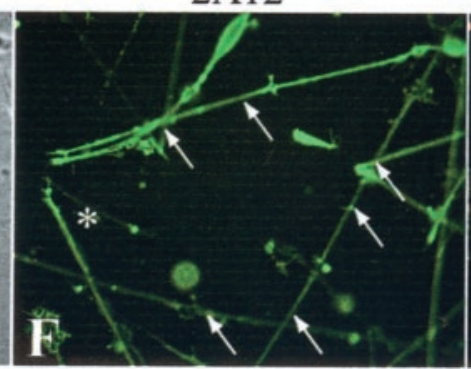

$\alpha-\mathrm{BTX}$

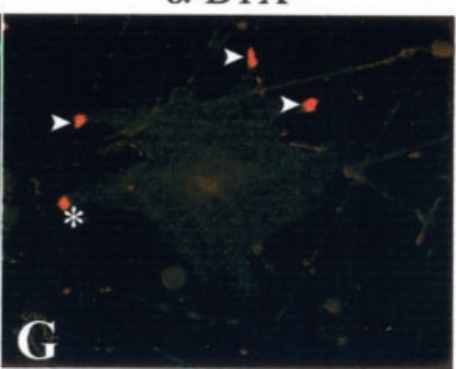

Merged

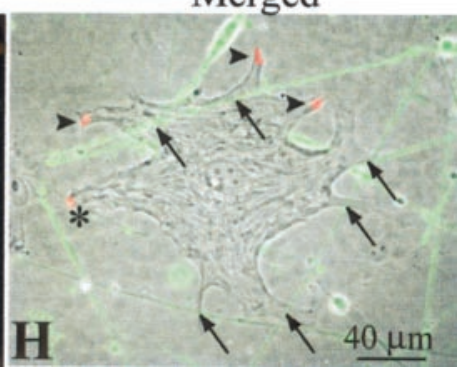

Figure 3. Adult Schwann cells enhance AChR aggregation on muscle in culture. Aggregation of AChRs on embryonic Xenopus SC $+\mathrm{M}$ cells for $7 \mathrm{~d}$ was compared with that in M. $A, B$, Phase-contrast images of an $\mathrm{SC}+\mathrm{M}$ culture $(A)$ and an $\mathrm{M}$ culture $(B)$ show similar muscle morphology. $A^{\prime}$, $B^{\prime}$, Fluorescence images of the same cultures labeled with Texas Red-conjugated $\alpha$-BTX show more AChR hotspots in SC+M than M. $C$, A plot shows a significant increase in the number of AChR hotspots per $100 \mu \mathrm{m}$ muscle length in SC+M, which was 2.2-fold of that in M. Treatment with heparin (300 $\mu \mathrm{g} / \mathrm{ml})$ eliminated this increase in the coculture $(\mathrm{SC}+\mathrm{M}+\mathrm{H})$, but the treatment did not show effect in pure muscle culture $(\mathrm{M}+\mathrm{H}) . D, \mathrm{~A}$ plot shows the 
contrast, only the B0 isoform was found in the $\mathrm{NMJ}$-poor region (Fig. 5C, NMJ-, lane 2), which consists mainly of muscle tissue. After acute ablation of PSCs in innervated muscle, active agrin bands (B11 and B19) became much weaker (Fig. 5C, lane 3; Table 1). Thus, the reduction in B11 and B19 is correlated with the absence of PSCs. The weaker bands of active isoforms in lane 3 after PSC ablation may originate, in part, from the unablated Schwann cells along intramuscular nerves (see Discussion). These axonal Schwann cells constitute $\sim 20 \%$ of the total number of Schwann cells as counted by nuclear staining (Hoechst 33342) in the CP muscle.

To investigate whether and how agrin expression in Schwann cells responds to nerve injury, we performed RT-PCR of reinnervated muscles (Fig. 5C). In reinnervated muscles 2 weeks after nerve transection, upregulation of B11/B19 and the appearance of B8 were found in the NMJ-rich tissue with intact PSCs (lane 5; compare with lane 1). This result is similar to the upregulation of active agrin isoforms in Schwann cells along regenerating sciatic nerves (Fig. $2 A$ ). After acute PSC ablation, the active agrin bands in the reinnervated NMJ-rich tissue were significantly weaker (compare lane 7 with lane 5), indicating that the active agrin mRNA was present in PSCs. These changes in agrin expression were quantified by comparing the relative intensity of various bands within the same lane (Table 1). After PSC ablation, the relative expression of active agrin isoforms in the $\mathrm{NMJ}$-rich tissue in innervated muscles was decreased from 37 to $14 \%$ of total agrin isoforms and in reinnervated muscles from 63 to $26 \%$ (Table 1). NMJ-poor regions showed no response to PSC ablation either with or without axotomy (Fig. $5 C$, lane 2 vs lane 4, lanes 6 vs lane 8 ). Thus, PSC ablation does not affect the agrin expression pattern in muscle.

\section{Extrajunctional AChR clusters are associated with PSC sprouts in vivo}

The expression of active agrin isoforms and their upregulation in PSCs after nerve regeneration suggested that PSCs might also play a role in the aggregation of AChRs in vivo. Because of the close apposition between PSCs and nerve terminals, it is impossible to distinguish the contribution of PSCs to AChR aggregation from that of nerve terminals in normal muscles. To circumvent this difficulty, we took advantage of the fact that PSCs sprout, often tens of micrometers, beyond the tips of regenerating nerve terminals during reinnervation (Koirala et al., 2000). This allowed us to examine in vivo whether PSCs play a role in AChR aggregation independent of nerve terminals. CP muscles of adult frog (Rana pipiens) were excised 17-28 d after axotomy, when many NMJs bore PSC sprouts longer than corresponding regenerating nerve terminals (Koirala et al., 2000) and then were fluorescently stained for AChRs, PSCs, axons, and nerve terminals. Figure 6 shows an example of an NMJ with extrajunctional AChR aggregation associated with PSC sprouts 4 weeks after axotomy. A prominent PSC sprout labeled with mAb $2 \mathrm{~A} 12$ (Fig. $6 A$, arrowhead) extended over $100 \mu \mathrm{m}$ beyond the boundary of
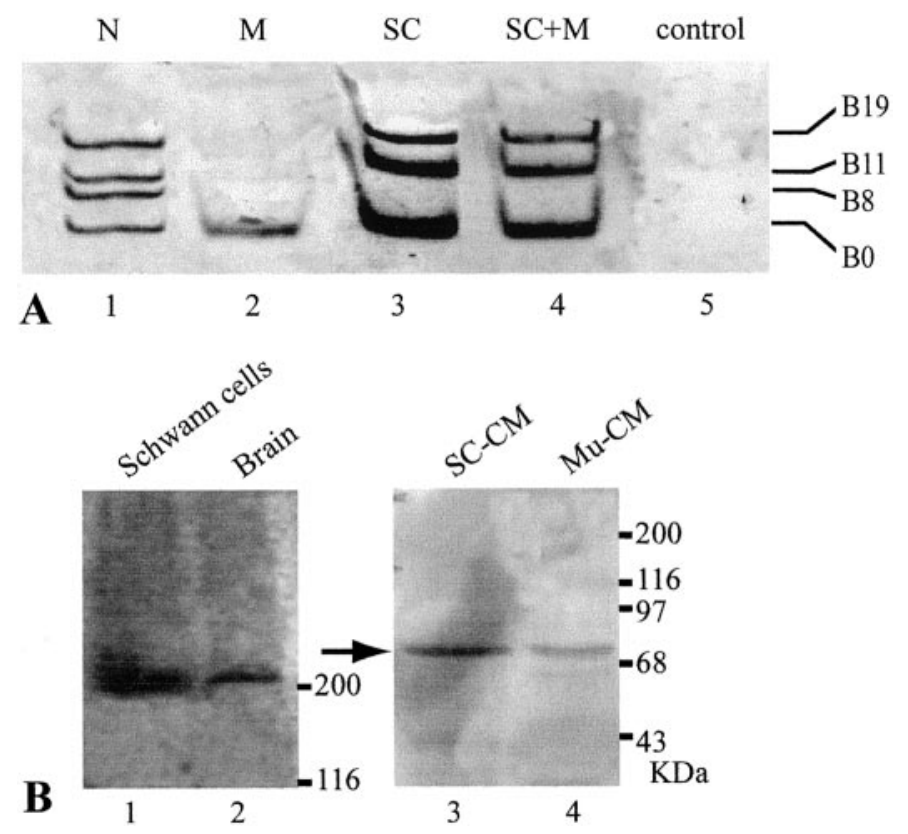

Figure 4. Agrin expression in adult Xenopus Schwann cells in vitro. A, Agrin isoform expression in cultured Schwann cells was examined by RT-PCR. Lane 1, As a positive control, spinal neurons in culture showed all four agrin isoforms. Lane 2, Muscle in culture displayed only the B0 isoform. Lane 3, Schwann cells in culture expressed B0, B11, and B19 isoforms. Lane 4, $\mathrm{SC}+\mathrm{M}$ for $7 \mathrm{~d}$ also showed B0, B11, and B19 isoforms. Lane 5, As a negative control, the lane showed no bands when no RNA samples were used for RT-PCR. B, Agrin protein in cultured Schwann cells and conditioned media was detected by Western blot using the anti-agrin antibody C3. Lane 1, Native agrin protein over $200 \mathrm{kDa}$ was detected in the total cell lysate of cultured Schwann cells. Lane 2, As a positive control, brain tissues showed similar immunoreactivity over 200 $\mathrm{kDa}$. Conditioned media of Xenopus Schwann cells cultured for 6 weeks (SC-CM; lane 3) and Xenopus muscle conditioned media from day 7 in culture (Mu-CM; lane 4 ) showed a positive band at $\sim 70 \mathrm{kDa}$ (arrow), but bands over $200 \mathrm{kDa}$ were absent. The $70 \mathrm{kDa}$ band may be an inactive degradation product of native agrin protein.

the original synaptic site (Fig. $6 A, B, D$, arrows), which was marked by AChE staining (Fig. $6 D$ ). Large and diff use AChR aggregates labeled with $\alpha$-BTX staining (Fig. 6B, arrowhead) were associated with the PSC sprout. Although regenerating nerve terminals were observed in neighboring junctional branches (Fig. 6C, asterisk), nerve terminals and axons were absent along these extrajunctional AChR aggregates (Fig. 6C, arrowhead), suggesting that PSCs directly induce such extrajunctional AChR aggregates. In contrast to the junctional AChRs, which appeared as bright bands and were sharply colocalized with the original junctional site, the extrajunctional AChRs appeared less dense and were not strictly confined by the boundary of the PSC sprouts (compare the region marked by the arrowhead in $A$ with that in $B$ ). This lack of precise colocalization between the extrajunctional AChRs and PSC sprouts indicates that the AChR clusters are not on the PSC

\footnotetext{
total area (in square micrometers) of $\mathrm{AChR}$ clusters per $100 \mu \mathrm{m}$ of muscle length in $\mathrm{SC}+\mathrm{M}, \mathrm{M}$, and after heparin treatment in $\mathrm{SC}+\mathrm{M}+\mathrm{H}$ and $\mathrm{M}+\mathrm{H}$. Similar to $C$, the area of AChR clusters in SC+M was significantly enlarged to 4.5-fold of that in M, and this increase was eliminated by heparin treatment. In $C$ and $D, n$ denotes the number of muscle fibers observed, and all values are mean $\pm \mathrm{SD}$. $E-H, \mathrm{SC}+\mathrm{M}$ cocultures were examined to determine the spatial relationship between AChR aggregates and Schwann cell-muscle contacts. The contacts (arrows) could be observed with phase contrast optics $(E)$ and confirmed with staining of Schwann cells with mAb 2A12 $(F)$. The same culture double-labeled with $\alpha$-BTX $(G)$ showed that the majority of these contacts were not colocalized with AChR clusters (arrowheads). Only in rare cases were AChR clusters colocalized with the Schwann cell-muscle contact (asterisk). The spatial relationship between AChR clusters and the contacts is further shown in $H$, which is a merged image of $E-G$.
} 
Figure 5. Agrin expression in perisynaptic Schwann cells at the neuromuscular junction. $A$, PSCs at the NMJ were selectively ablated in vivo by labeling the PSC membrane with $\mathrm{mAb}$ 2A12 and subsequent application of guinea pig complement, which forms membrane attack complexes and lyses cells. PSC lysis was revealed by ethidium homodimer-1, which enters cells with damaged membranes and stains their nuclei (in red, arrows). PSCs (in green) were revealed by labeling with FITC-conjugated secondary antibody to mAb $2 \mathrm{~A} 12$. Over $80 \%$ of PSCs were ablated by this technique. $B, A$ control muscle treated with complement alone did not show dead PSCs (arrows mark nuclei of living PSCs). On average, $<5 \%$ of PSCs were ablated in the absence of mAb 2A12. PSCs in the control group were revealed with FITCconjugated peanut agglutinin (in green). $C$, The acute effect of PSC ablation on agrin expression in normal and reinnervated muscles was examined by RT-PCR. Within the NMJ-rich region of intact $\mathrm{CP}$ muscle $(P S C+)$, agrin expression typical of adult Schwann cells was observed (lane 1, compare with Fig. 2A, Intact), whereas only the B0 isoform was found in the NMJ-poor region (NMJ-, lane 2), which consists mainly of muscle tissue. When PSCs were killed, active agrin bands (B11 and B19) became much weaker (lane 3). With PSCs intact, 2 weeks after axotomy, nerve regeneration induced the upregulation of B11/B19 and the appearance of B8 (lane 5), similar to Schwann cells along the regenerated sciatic nerve (lane 5, compare with Fig. $2 A$ ). This upregulation of active isoforms was significantly weaker after PSC ablation (lane 7). NMJ-poor regions showed no response to PSC ablation either with or without denervation (lane 2 vs lane 4, lane 6 vs lane 8). Lane 9, As a negative control, the lane showed no bands when no RNA samples were used for RT-PCR.
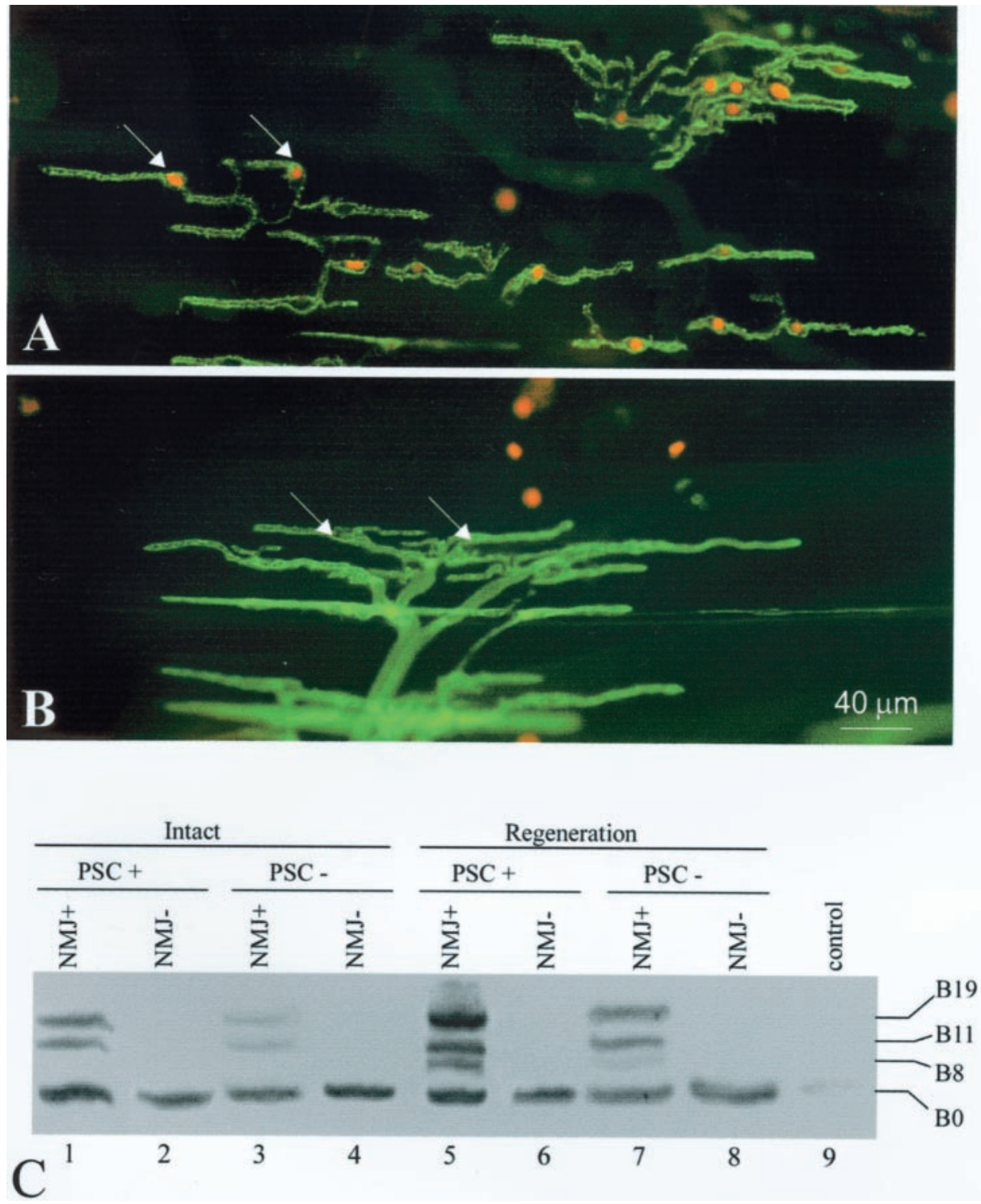

membrane but rather on muscle. Furthermore, some extrajunctional AChR clusters show a staining pattern that resembles sarcomeres. Figure $6 E$ shows an example of this "sarcomeric" pattern revealed in a high-magnification view of the extrajunctional AChR cluster marked by the arrowhead in Figure $6 B$. The brighter stripes of AChR staining match with the light bands of sarcomeres in the same region of the muscle fiber (Fig. $6 F$ ). The sarcomeric pattern is not an artifact of intracellular staining of sarcomeres with $\alpha$-BTX because the pattern was also seen in muscle that was freshly dissected and labeled with $\alpha$-BTX without any previous fixation, membrane permeabilization, or other staining procedures (Fig. $6 G$ ). The more pronounced sarcomeric pat-

\section{Table 1. PSC agrin expression before and after selective PSC ablation}

\begin{tabular}{|c|c|c|c|c|c|}
\hline Lane & PSC & Innervation & $\begin{array}{l}\text { B0 } \\
\text { (\% of total) }\end{array}$ & $\begin{array}{l}\text { B8 } \\
\text { (\% of total) }\end{array}$ & $\begin{array}{l}\mathrm{B} 8+\mathrm{B} 11+\mathrm{B} 19 \\
(\% \text { of total })\end{array}$ \\
\hline 1 & $\mathrm{PSC}+$ & Intact & $63 \pm 6$ & 0 & $37 \pm 5$ \\
\hline 3 & PSC - & Intact & $86 \pm 2$ & 0 & $14 \pm 1$ \\
\hline 5 & PSC + & Regeneration & $38 \pm 2$ & $9 \pm 2$ & $63 \pm 4$ \\
\hline 7 & PSC - & Regeneration & $72 \pm 4$ & $2 \pm 1$ & $26 \pm 3$ \\
\hline
\end{tabular}

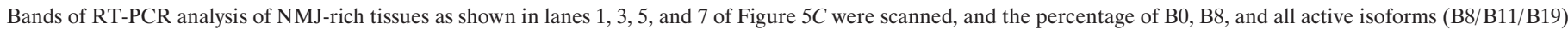

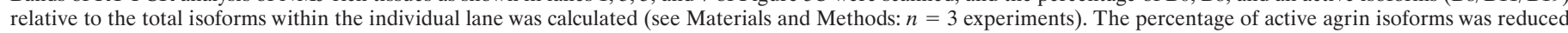

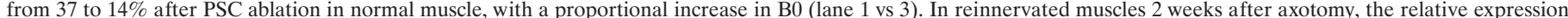

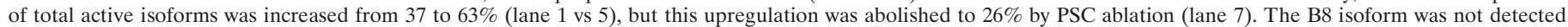

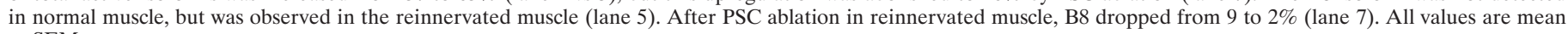
\pm SEM. 

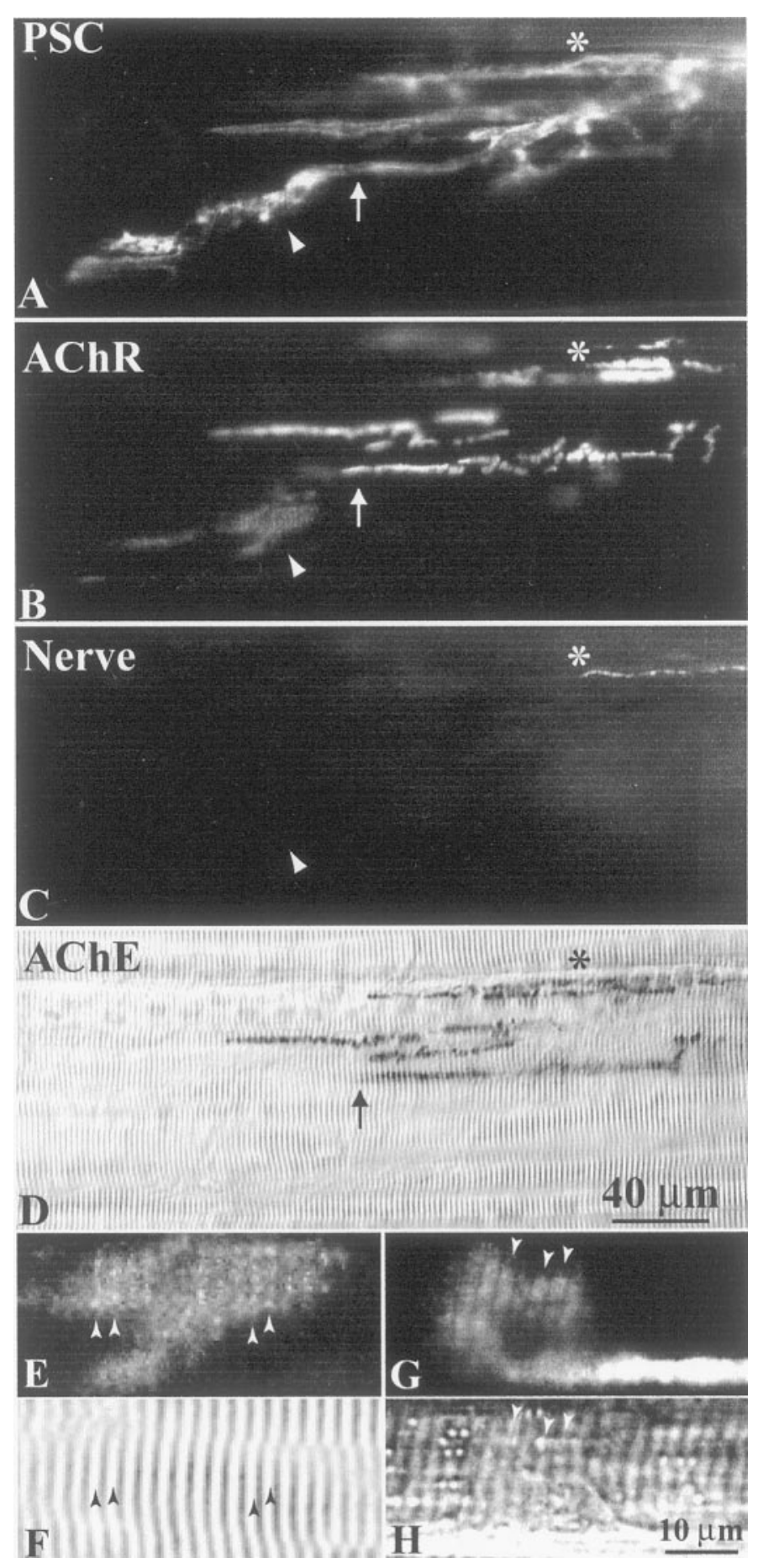

Figure 6. PSC sprouts may induce AChR aggregation in vivo. NMJs 4 weeks after axotomy were fluorescently labeled with $\mathrm{mAb} 2 \mathrm{~A} 12$ for PSCs $(A), \alpha$-BTX for AChRs $(B)$, and antibodies to neurofilament $200 \mathrm{kDa}$ and synapsin I for axons and nerve terminals, respectively $(C)$. $A$, A prominent PSC sprout (arrowhead) extended beyond the boundary of the original junction delineated by $\mathrm{AChE}$ (arrow in $D$; corresponding arrows in $A$ and $B$ ). $B$, A large extrajunctional AChR aggregate (arrowhead) colocalized with the PSC sprout (arrowhead in $A$ ). $C$, Axons and nerve terminals were absent from extrajunctional AChR aggregates (arrowhead) and PSC sprouts, suggesting that PSC sprouts may directly induce AChR clustering in vivo. Asterisk marks the closest extent of regenerating nerve terminals. $D$, The original synaptic sites were labeled with Karnovsky's AChE stain. The scale bar in $D$ applies to $A-D$. E, A high-magnification view of the AChR aggregate marked by the arrowhead in $B$. F, Bright-field view of the same region of the muscle fiber as in $E$. The AChR aggregate tern seen in Figure $6 G$ again matches with the light bands of sarcomeres (Fig. 6H). PSC-associated AChRs with the sarcomeric pattern and weaker staining than the junctional AChRs were also observed with an antibody to the $\delta$ subunit of the nicotinic AChR (data not shown). Besides PSC-associated extrajunctional AChR clusters, small speckles of $\mathrm{AChRs}(\sim 1-5 \mu \mathrm{m})$ randomly distributed over the muscle surface were also seen with $\alpha$-BTX or anti-AChR staining in denervated and reinnervated muscles (data not shown). These speckles were too small to reveal the sarcomeric pattern and were not further examined in the present study.

To further test whether PSC sprouts play a role in the aggregation of extrajunctional AChRs as exemplified by Figure 6, the degree of association between extrajunctional AChR aggregates and PSC sprouts in reinnervated muscles was quantified 17-28 d after axotomy ( $n=225$ aggregates, 8 muscles). We found that $88 \%$ of extrajunctional AChR aggregates were associated with PSC sprouts, whereas $12 \%$ were distributed over the remaining muscle surface. Some of the latter aggregates also showed the sarcomeric pattern. We showed previously that Schwann cell sprouts are induced by regenerating nerve terminals (Koirala et al., 2000). Consistent with this finding, most of the PSC sprouts associated with extrajunctional AChR aggregates were also accompanied by regenerating nerve terminal sprouts. The $88 \%$ of PSC-associated aggregates mentioned above included $74 \%$ that showed overlying nerve terminal sprouts and $14 \%$ that were devoid of nerve terminals. To exclude extrajunctional AChR aggregation probably caused by nerve terminal sprouts, we focused solely on the 14\% (32 of 225) of aggregates that were colocalized with PSC sprouts alone and, on average, $17 \pm 5 \mu \mathrm{m}$ away from the closest nerve terminals or axons.

To exclude the possibility that the association between PSC sprouts and extrajunctional AChR aggregates was by chance, a statistical analysis was performed (see Materials and Methods). If randomly distributed, only $0.6 \%$ of the 58 extrajunctional AChR aggregates not associated with nerve terminals would colocalize with PSC sprouts alone, and $99.4 \%$ would be distributed over the remaining muscle surface (excluding areas under axons and nerve terminals). However, we found that $55.2 \%$ (32 of 58) of extrajunctional AChR aggregates were associated with PSC sprouts alone, which is significantly greater than random association $(p<$ $10^{-5} ; \chi^{2}$ test). In addition, PSC-associated extrajunctional AChR aggregates were significantly larger ( $p<0.05$; Student's $t$ test) than randomly distributed aggregates $(31 \pm 9$ vs $14 \pm 4 \mu \mathrm{m}$ in length. Furthermore, we found that $52 \%$ of PSC sprouts without accompanying nerve terminals ( $n=56,8$ muscles) showed associated AChR aggregates. Together, these in vivo results suggest that PSC sprouts may induce AChR aggregation after nerve injury.

\section{DISCUSSION}

The present study demonstrates that adult Schwann cells express active agrin isoforms and that this expression is upregulated by

\section{$\leftarrow$}

showed sarcomeric staining pattern with stripes of brighter AChRs (arrowheads in $E$ ) matching with the light bands (arrowheads in $F$ ) of sarcomeres. $G$, An extrajunctional AChR aggregate in a reinnervated muscle (3 weeks after axotomy), which was freshly dissected and labeled with $\alpha$-BTX without previous fixation, membrane permeabilization, or other staining procedures. $H$, Bright-field view of the same region of the muscle fiber as in $G$. The sarcomeric pattern also showed brighter stripes of AChRs (arrowheads in $G$ ) matching with the light bands (arrowheads in $H$ ) of sarcomeres. The scale bar in $H$ applies to $E-H$. 
axonal regeneration. Adult Schwann cells enhance the aggregation of AChRs on muscle fibers in vitro. Although the evidence is indirect, our results are consistent with the hypothesis that the enhancement of AChR aggregation by cultured Schwann cells is mediated by agrin. Using complement-mediated lysis to selectively ablate PSCs at the NMJ in vivo, we show that these synapse-associated glial cells also express active agrin isoforms. Finally, we present evidence that PSCs may induce AChR clusters in vivo. These novel findings suggest that, in addition to neurons, glial cells also play a role in the aggregation of postsynaptic receptors. Receptor aggregation by glia may complement the role of neurons and may be particularly important in ensuring rapid restoration of synaptic function during regeneration.

\section{Adult Schwann cells express active agrin isoforms}

Werle et al. (1999) have reported that Schwann cells in the frog sciatic nerve express only the inactive B0 isoform. However, using the same preparation and the same primers for RT-PCR, we found that frog Schwann cells do express the active agrin isoforms B11 and B19, besides the inactive B0. One possible explanation for the conflicting result may be attributed to different amount of RNA, or different temperature and number of cycles, used for our RT-PCR. To exclude the possibility of false-positive bands in our samples, we subcloned each PCR fragment and confirmed its sequence as agrin. The expression of active agrin isoforms is not an artifact of contamination by neuronal mRNA that might be present in axons or nerve terminals, because the sciatic nerve samples used for our RT-PCR study did not contain any neurofilament mRNA. In addition, we showed that Schwann cells cocultured with muscles, but devoid of neurons, also express active agrin isoforms. Furthermore, if our RT-PCR samples were contaminated with neuronal agrin mRNA, we would detect all four agrin isoforms, including B8, as found in the spinal cord. However, the B8 isoform was not observed in Schwann cells along normal sciatic nerve, in nerve terminals, or in cultured Schwann cells. Moreover, B11 and B19 isoforms were also expressed in the chronically segregated distal segment of the sciatic nerve. Because the half-life of mRNAs in animal cells is usually $<24 \mathrm{hr}$ (Lewin and Siliciano, 1996), the active agrin isoforms in the distal nerve segment seen even at 6 weeks after long-term denervation must be actively transcribed, most likely by Schwann cells along the nerve. Contamination of active agrin from other cell types is also unlikely; Schwann cells are the predominant cell type along the nerve fiber, and we found that fibroblasts in the epineurial sheath do not express any agrin isoforms. Together, these results demonstrate that adult Schwann cells express active agrin isoforms. Anti-agrin staining has also been observed at frog PSCs (Werle et al., 1999). However, it is not possible to distinguish between the active and inactive forms of agrin proteins using the currently available antibodies.

\section{Expression of Schwann cell agrin during development and axonal regeneration}

Similar to embryonic Schwann cells in the chick sciatic nerve, which express only B0 (Ruegg et al., 1992), developing Schwann cells in tadpoles do not express active agrin. Although it is not known how the expression of B11 and B19 is triggered in Schwann cells during metamorphosis, it is clear that the expression of these active isoforms occurs long after synaptogenesis. Thus, the expression of B11 and B19 isoforms by Schwann cells during development is not induced by innervation per se. The absence of active agrin expression in tadpole Schwann cells also indicates that Schwann cell-derived agrin is unlikely to play a role in the aggregation of AChRs during initial synaptogenesis. Consistent with this view, there is no AChR clustering along Schwann cell sprouts that extend beyond developing nerve terminals during synapse formation in tadpole muscles (Herrera et al., 2000). This is in contrast to adult muscles, in which aggregates of AChRs are formed along PSC sprouts after nerve injury and reinnervation (see below).

In adult animals, expression of all active agrin isoforms in Schwann cells was upregulated after nerve injury. However, the upregulation is not attributable to nerve injury per se because no upregulation occurs in Schwann cells along chronically severed nerve fibers. Rather, the upregulation of active agrin isoforms coincides with axonal regeneration, suggesting that regenerating nerves play a role in the upregulation. This upregulation of active agrin isoforms is reminiscent of the induction of PSC sprouting, which also occurs in response to nerve regeneration, but not nerve injury alone, at the frog NMJ (Koirala et al., 2000). The mechanism underlying activation of Schwann cells by regenerating axons and nerve terminals is unknown.

\section{Schwann cells enhance AChR aggregation in vitro}

Koenig et al. (1998) suggested that chick Schwann cells have the capacity to enhance AChR aggregation on cultured myotubes. The present study has shown that cultured adult Schwann cells express active agrin mRNAs and produce native agrin protein. In addition, adult Schwann cells increase the number and area of AChR hotspots on Xenopus muscle in culture, and the increase in AChR aggregation is eliminated by heparin. These findings are consistent with the hypothesis that the enhancement of AChR aggregation by Schwann cells is mediated by agrin. However, besides disrupting agrin function (Hopf and Hoch, 1997), heparin has been shown to also interfere with the function of neuregulin, laminin, and other molecules that affect AChR synthesis and clustering (Yarden and Wen, 1994). Thus, we cannot exclude the possibility that other soluble molecules released by Schwann cells may also play a role in the enhancement of AChR aggregation. Unfortunately, the lack of antibodies that perturb the function of Xenopus agrin prevented us from testing the direct involvement of agrin in $\mathrm{SC}+\mathrm{M}$ cocultures.

The absence of enhancement of AChR aggregation by Schwann cell-conditioned medium also precluded our attempt to use immunoprecipitation to directly test the role of Schwann cell-derived agrin. In the Schwann cell-conditioned medium, we only detected a $70 \mathrm{kDa}$ band, which likely represents a degradation product of the agrin protein and is probably not active in AChR aggregation (Nitkin et al., 1987). The absence of protein bands above $200 \mathrm{kDa}$ in the conditioned medium may be attributable to the fact that the conditioned medium was collected from long-term cultures, and thus most native agrin protein was degraded. This is in contrast to the increase in AChR aggregation observed in SC+M cocultures (Fig. 3). In the cocultures, Schwann cells may continuously release native agrin protein, which presumably would have an immediate and cumulative effect on AChR aggregation before being degraded.

\section{Expression of active agrin in the PSC}

The present study has applied a novel technique using complement-mediated lysis to selectively ablate PSCs (Reddy et al., 1999) (a full-length paper will be published in the future). Ablation of PSCs caused a reduction in the amount of active agrin isoforms, indicating that, similar to axonal Schwann cells, 
PSCs also express active agrin genes. As shown in Astrow et al. (1998), Schwann cells along axons are not labeled by mAb 2 A12 in whole-mount preparations and thus are not ablated by the complement treatment. Because $\sim 20 \%$ of the total Schwann cells in the $\mathrm{CP}$ muscle belong to these axonal Schwann cells and typically $\sim 20 \%$ of PSCs were not ablated by the mAb 2 A12 plus complement treatment, these remaining Schwann cells might contribute to the active agrin isoforms still seen after the ablation treatment in intact and reinnervated muscles (Table 1). Our approach using PSC ablation and RT-PCR has provided evidence, albeit indirect, that is consistent with the idea that PSCs also express active agrin isoforms and the expression is upregulated by reinnervation.

\section{Extrajunctional AChRs are associated with PSC sprouts in vivo}

The present study has shown that, during muscle reinnervation, clusters of AChRs form outside of original synaptic sites and that these clusters colocalize with PSC sprouts. Because the density of AChRs falls sharply within a few micrometers of nerve terminals at the NMJ (Matthews-Bellinger and Salpeter, 1978), it is unlikely that neuronal agrin would have a diffusible effect on the aggregation of extrajunctional AChRs located tens of micrometers away as observed in the present study. It is also unlikely that the extrajunctional AChR aggregation is caused by nerve terminals that extended and then retracted before our observations. Using repeated observation of identified NMJs in living frogs, we showed previously extension of PSC sprouts tens or hundreds of micrometers longer than nerve terminals; in many cases, PSC sprouts continued to extend even when nerve terminals showed no change in length during a period of 2-3 months of multiple observations (Chen et al., 1991; Chen and Ko, 1994; Ko and Chen, 1996). Thus, frog nerve terminals do not extend and then retract through such long distances. Furthermore, we showed recently that, at early stages of reinnervation (2-4 weeks after axotomy), there is substantial growth of nerve terminals but virtually no observed retraction (Koirala et al., 2000). Thus, the clusters of extrajunctional AChRs were most likely caused by PSC sprouts rather than by nerve terminals that extended and then retracted.

The association of AChR aggregates and PSC sprouts is not random. In stark contrast to the predicted value of $0.6 \%$ if the association were purely by chance, we showed that $55.2 \%$ of extrajunctional AChR clusters (without accompanying nerve terminals) are located at PSC sprouts. Furthermore, 52\% of PSC sprouts (without accompanying nerve terminals) showed the presence of colocalized extrajunctional AChRs, consistent with the suggestion that PSC sprouts play a role in the AChR aggregation.

The mechanism of PSC-induced AChR aggregation in vivo is not known. Because PSCs express active agrin, it is tempting to speculate that the aggregation of extrajunctional AChRs is mediated by agrin released by PSCs. The colocalization between AChR clusters and PSC sprouts in vivo would suggest that agrin molecules, if released by PSC sprouts, probably bind basal lamina and are concentrated locally, as is the case for neuronal agrin at the NMJ. In contrast to the in vivo finding, Schwann cellenhanced AChR aggregation in vitro is independent of cell contact, which may be attributed to the paucity of basal lamina on embryonic muscle fibers in culture.

As in the present study, discrete patches of extrajunctional AChRs with different shape and lower density than the junctional
AChRs have been reported in denervated mammalian muscles (Ko et al., 1977). Clusters of AChR with various densities have also been observed in muscles treated with agrin in vitro (Wallace, 1992) or in vivo (Bezakova et al., 2001). In fact, the sarcomeric pattern can also be discerned in some extrajunctional AChR clusters induced by agrin application to rat muscle (Bezakova et al., 2001, their Fig. 4). Because the sarcomeric pattern of AChR staining matches with the light bands of the sarcomere, it is likely that AChRs are located in and around the T tubules, which have membrane invaginations near the Z-line in the light bands. Sheikh et al. (2001) have shown that sodium channels cluster selectively around the mouths of the T tubules in the frog skeletal muscle fiber. It is possible that AChRs also cluster only around the mouths of the T tubules. Alternatively, AChRs may be evenly distributed along the entire length of the $\mathrm{T}$ tubules, but their invaginations give rise to a brighter signal of AChR staining in the en face view.

The novel role of glial cells in receptor aggregation described in this study may be important in laying the groundwork for rapid and successful restoration of synaptic function during regeneration. In addition to the presynaptic guidance of regenerating nerve terminals as shown previously (for review, see Son et al., 1996), PSCs now appear to play a postsynaptic role in inducing AChR aggregation ahead of regenerating terminals. There is indirect evidence that PSC-induced AChR aggregates may constitute sites of subsequent synaptogenesis. PSCs sprout soon after regenerating nerve terminals arrive at endplates, and nerve terminals grow along PSC sprouts (Koirala et al., 2000). Because AChR aggregates are present along PSC sprouts ahead of nerve terminals, these aggregates would very likely be "innervated" by the regenerating nerve terminals. Consistent with this scenario, we observe that, at later stages of reinnervation, all extrajunctional AChR aggregates colocalize with overlying nerve terminals (Koirala et al., 2000). Apart from a preparatory role in reinnervation, our results suggest that PSCs could also play a role in the maintenance of AChRs at the NMJ. Studies are underway using our novel PSC ablation technique to determine whether PSCs play a role in the maintenance of AChR clustering at NMJs, particularly after nerve injury.

\section{REFERENCES}

Araque A, Parpura V, Sanzgiri RP, Haydon PG (1999) Tripartite synapses: glia, the unacknowledged partner. Trends Neurosci 22:208-215.

Astrow SH, Qiang H, Ko C-P (1998) Perisynaptic Schwann cells at neuromuscular junctions revealed by a novel monoclonal antibody. J Neurocytol 27:667-681.

Bacci A, Verderio C, Pravettoni E, Matteoli M (1999) The role of glial cells in synaptic function. Philos Trans R Soc Lond B Biol Sci 354:403-409.

Bezakova G, Helm JP, Francolini M, Lomo T (2001) Effects of purified recombinant neural and muscle agrin on skeletal muscle fibers in vivo. J Cell Biol 153:1441-1452.

Brockes JP, Fields KL, Raff MC (1979) Studies on cultured rat Schwann cells. I. Establishment of purified populations from cultures of peripheral nerve. Brain Res 165:105-118.

Cao G, Qiang H, Ko C-P (1999) The effect of Schwann cells on acetylcholine receptor aggregates in Xenopus nerve-muscle cultures. Soc Neurosci Abstr 25:240.

Castonguay A, Robitaille R (2001) Differential regulation of transmitter release by presynaptic and glial $\mathrm{Ca}^{2+}$ internal stores at the neuromuscular synapse. J Neurosci 21:1911-1922.

Chen L, Ko C-P (1994) Extension of synaptic extracellular matrix during nerve terminal sprouting in living frog neuromuscular junctions. J Neurosci 14:796-808.

Chen L, Folsom DB, Ko C-P (1991) The remodeling of synaptic extracellular matrix and its dynamic relationship with nerve terminals at living frog neuromuscular junctions. J Neurosci 11:2920-2930.

Cohen MW, Anderson MJ, Zorychta E, Weldon PR (1979) Accumulation of acetylcholine receptors at nerve-muscle contacts in culture. Prog Brain Res 49:335-349. 
Daggett DF, Stone D, Peng HB, Nikolics K (1996) Full-length agrin isoform activities and binding site distributions on cultured Xenopus muscle cells. Mol Cell Neurosci 7:75-88.

Ferns M, Hock W, Campanelli JT, Rupp F, Hall ZW, Scheller RH (1992) RNA spicing regulates agrin-mediated acetylcholine receptor clustering activity on cultured myotubes. Neuron 8:1079-1086.

Ferns M, Campanelli JT, Hock W, Scheller RH, Hall ZW (1993) The ability of agrin to cluster AChRs depends on alternative splicing and on cell surface proteoglycans. Neuron 11:491-502.

Frank E, Fischbach GD (1979) Early events in neuromuscular junction formation in vitro: induction of acetylcholine receptor clusters in the postsynaptic membrane and morphology of newly formed synapses. J Cell Biol 83:143-158.

Georgiou J, Robitaille R, Trimble WS, Charlton MP (1994) Synaptic regulation of glial protein expression in vivo. Neuron 12:443-455.

Gervasi C, Szaro BG (1997) Sequence and expression patterns of two forms of the middle molecular weight neurofilament protein (NF-M) of Xenopus laevis. Mol Brain Res 48:229-242.

Gesemann M, Denzer A, Ruegg MA (1995) Acetylcholine receptoraggregating activity of agrin isoforms and mapping of the active site. J Cell Biol 128:625-636.

Godfrey EW, Dietz ME, Morstad AL, Wallskog PA, Yorde DE (1988) Acetylcholine receptor-aggregating proteins are associated with the extracellular matrix of many tissue in Torpedo. J Cell Biol 106:1263-1272.

Herrera AA, Qiang H, Ko C-P (2000) The role of perisynaptic Schwann cells in development of neuromuscular junctions in the frog (Xenopus laevis). J Neurobiol 45:237-254.

Hopf C, Hoch W (1997) Heparin inhibits acetylcholine receptor aggregation at two distinct steps in the agrin-induced pathway. Eur J Neurosci 9:1170-1177.

Howard J, Hughes-Jones N (1988) Complement-mediated lysis with monoclonal antibodies. Prog Allergy 45:1-15.

Karnovsky MJ (1964) The localization of cholinesterase activity in rat cardiac muscle by electron microscopy. J Cell Biol 23:217-232.

Ko C-P (1987) A lectin, peanut agglutinin, as a probe for the extracellular matrix in living neuromuscular junction. J Neurocytol 16:567-576.

Ko C-P, Chen L (1996) Synaptic remodeling revealed by repeated in vivo observations and electron microscopy of identified frog neuromuscular junctions. J Neurosci 16:1780-1790.

Ko PK, Anderson MJ, Cohen MW (1977) Denervated skeletal muscle fibers develop discrete patches of high acetylcholine receptor density. Science 196:540-542.

Koenig J, de La Porte S, Chapron J (1998) The Schwann cell at the neuromuscular junction. J Physiol (Paris) 92:153-155.

Koirala S, Qiang H, Ko C-P (2000) Reciprocal interactions between perisynaptic Schwann cells and regenerating nerve terminals at the frog neuromuscular junction. J Neurobiol 44:343-360.

Lewin B, Siliciano P (1996) Genes VI, p 165. New York: Oxford UP.

Ma E, Morgan R, Godfrey EW (1994) Distribution of agrin mRNAs in the chick embryo nervous system. J Neurosci 14:2943-2952.

Matthews-Bellinger J, Salpeter MM (1978) Distribution of acetylcholine receptors at frog neuromuscular junctions with a discussion of some physiological implications. J Physiol (Lond) 279:197-213.

McMahan UJ (1990) The agrin hypothesis. Cold Spring Harb Symp Quant Biol 55:407-418.

Nieuwkoop PK, Faber J (1994) Normal table of Xenopus laevis (Daudin): a systematical and chronological survey of development from the fertilized egg till the end of metamorphosis, pp 162-188. New York: Garland.

Nitkin RM, Smith MA, Magill C, Fallon JR, Yao YM, Wallace BG, McMahan UJ (1987) Identification of agrin, a synaptic organizing protein from Torpedo electric organ. J Cell Biol 105:2471-2478.

O'Malley JP, Waran MT, Balice-Gordon RJ (1999) In vivo observations of terminal Schwann cells at normal, denervated, and reinnervated mouse neuromuscular junctions. J Neurobiol 38:270-286.

Qiang H, Koirala S, Ko C-P (1998) Do Schwann cells play a role in aggregation of acetylcholine receptors at the neuromuscular junction? Soc Neurosci Abstr 24:1036.

Reddy LV, Koirala S, Ko C-P (1999) Selective ablation of perisynaptic Schwann cells from the frog neuromuscular junction in vivo. Soc Neurosci Abstr 25:2032.

Reynolds ML, Woolf CJ (1992) Terminal Schwann cells elaborate extensive processes following denervation of the motor endplate. J Neurocytol 21:50-66.

Robitaille R (1998) Modulation of synaptic efficacy and synaptic depression by glial cells at the frog neuromuscular junction. Neuron 21:847-855.

Ruegg MA, Bixby JL (1998) Agrin orchestrates synaptic differentiation at the vertebrate neuromuscular junction. Trends Neurosci 21:22-27.

Ruegg MA, Tsim KWK, Horton SE, Kroger S, Escher G, Gensch EM, McMahan UJ (1992) The agrin gene codes for a family of basal lamina proteins that differ in function and distribution. Neuron 8:691-699.

Sambrook J, Russell DW (2001) Molecular cloning - a laboratory manual (Argentine J ed), pp A8.40-A8.55. New York: Cold Spring Harbor Laboratory.

Sanes JR, Lichtman JW (1999) Development of the vertebrate neuromuscular junction. Annu Rev Neurosci 22:389-442.

Sheikh SM, Skepper JN, Chawla S, Vandenberg JI, Elnei S, Huang CL-H (2001) Normal conduction of surface action potentials in detubulated amphibian skeletal muscle fibres. J Physiol (Lond) 535:579-590.

Smith MA, O'Dowd DK (1994) Cell-specific regulation of agrin RNA splicing in the chick ciliary ganglion. Neuron 12:795-804.

Son YJ, Thompson WJ (1995a) Schwann cell processes guide regeneration of peripheral axons. Neuron 14:125-132.

Son YJ, Thompson WJ (1995b) Nerve sprouting in muscle is induced and guided by processes extended by Schwann cells. Neuron 14:133-141.

Son YJ, Trachtenberg JT, Thompson WJ (1996) Schwann cells induce and guide sprouting and reinnervation of neuromuscular junctions. Trends Neurosci 19:280-285.

Tabti N, Poo MM (1994) Study on the induction of spontaneous transmitter release at early nerve-muscle contacts in Xenopus cultures. Neurosci Lett 173:21-26.

Tsim KWK, Ruegg MA, Escher G, Kroger S, McMahan UJ (1992) cDNA that encodes active agrin. Neuron 8:677-689.

Wallace B (1992) Mechanism of agrin-induced acetylcholine receptor aggregation. J Neurobiol 23:592-604.

Werle MJ, Jones MA, Stanco AM (1999) Aggregates of acetylcholine receptors are not observed under anti-agrin staining Schwann cell processes at the frog neuromuscular junction. J Neurobiol 40:45-54.

Yang JF, Ko C-P (1999) Expression of agrin by Schwann cells at intact, degenerating and developing nerves. Soc Neurosci Abstr 25:240.

Yarden Y, Wen D (1994) Neu differentiation factor (NDF) and the neuregulin (NRG) family. In: Guidebook to cytokines and their receptors (Nicola NA, ed), pp 146-149. New York: Oxford UP. 